Article

\title{
Synthesis and Antifouling Activity Evaluation of Analogs of Bromosphaerol, a Brominated Diterpene Isolated from the Red Alga Sphaerococcus coronopifolius
}

\author{
Kyriakos C. Prousis $\left.{ }^{1}{ }^{(}\right)$, Stefanos Kikionis ${ }^{2}{ }^{(0)}$, Efstathia Ioannou $\left.{ }^{2}{ }^{(}\right)$, Silvia Morgana ${ }^{3}\left(\mathbb{D}\right.$, Marco Faimali $^{3}$, \\ Veronica Piazza $^{3, *}$, Theodora Calogeropoulou ${ }^{1, *}$ and Vassilios Roussis ${ }^{2, *}$ (i) \\ 1 Institute of Chemical Biology, National Hellenic Research Foundation, 48 Vassileos Constantinou Avenue, \\ 11653 Athens, Greece; kyrprous@eie.gr \\ 2 Section of Pharmacognosy and Chemistry of Natural Products, Department of Pharmacy, National and \\ Kapodistrian University of Athens, Panepistimiopolis Zografou, 15771 Athens, Greece; \\ skikionis@pharm.uoa.gr (S.K.); eioannou@pharm.uoa.gr (E.I.) \\ 3 Institute for the Study of Anthropic Impacts and Sustainability in Marine Environment (IAS), \\ National Research Council (CNR), Via De Marini 6, 16149 Genova, Italy; silvia.morgana@ias.cnr.it (S.M.); \\ marco.faimali@ias.cnr.it (M.F.) \\ * Correspondence: veronica.piazza@ias.cnr.it (V.P.); tcalog@eie.gr (T.C.); roussis@pharm.uoa.gr (V.R.); \\ Tel.: +39-010-6475409 (V.P.); +30-210-7273833 (T.C.); +30-210-7274592 (V.R.)
}

Citation: Prousis, K.C.; Kikionis, S.; Ioannou, E.; Morgana, S.; Faimali, M.; Piazza, V.; Calogeropoulou, T.;

Roussis, V. Synthesis and Antifouling Activity Evaluation of Analogs of Bromosphaerol, a Brominated Diterpene Isolated from the Red Alga Sphaerococcus coronopifolius. Mar. Drugs 2022, 20, 7. https://doi.org/ $10.3390 / \mathrm{md} 20010007$

Academic Editors: Margherita Gavagnin and Angelo Fontana

Received: 22 November 2021 Accepted: 14 December 2021

Published: 22 December 2021

Publisher's Note: MDPI stays neutral with regard to jurisdictional claims in published maps and institutional affiliations.

Copyright: (c) 2021 by the authors Licensee MDPI, Basel, Switzerland. This article is an open access article distributed under the terms and conditions of the Creative Commons Attribution (CC BY) license (https:// creativecommons.org/licenses/by/ $4.0 /)$.

\begin{abstract}
Marine biofouling is an epibiotic biological process that affects almost any kind of submerged surface, causing globally significant economic problems mainly for the shipping industry and aquaculture companies, and its prevention so far has been associated with adverse environmental effects for non-target organisms. Previously, we have identified bromosphaerol (1), a brominated diterpene isolated from the red alga Sphaerococcus coronopifolius, as a promising agent with significant antifouling activity, exerting strong anti-settlement activity against larvae of Amphibalanus (Balanus) amphitrite and very low toxicity. The significant antifouling activity and low toxicity of bromosphaerol (1) motivated us to explore its chemistry, aiming to optimize its antifouling potential through the preparation of a number of analogs. Following different synthetic routes, we successfully synthesized 15 structural analogs (2-16) of bromosphaerol (1), decorated with different functional groups. The anti-settlement activity $\left(\mathrm{EC}_{50}\right)$ and the degree of toxicity $\left(\mathrm{LC}_{50}\right)$ of the bromosphaerol derivatives were evaluated using cyprids and nauplii of the cirriped crustacean A. amphitrite as a model organism. Derivatives 2, 4, and 6-16 showed diverse levels of antifouling activity. Among them, compounds 9 and 13 can be considered as well-performing antifoulants, exerting their activity through a non-toxic mechanism.
\end{abstract}

Keywords: bromosphaerol; Sphaerococcus coronopifolius; synthetic analogs; antifouling activity; Amphibalanus amphitrite

\section{Introduction}

Marine biofouling is an epibiotic biological process that is characterized by the attachment of various micro- and macro-organisms of the marine environment on submerged surfaces [1-5]. It is a build-up process in which the initial conditioning film formation occurring over swamped surfaces is followed by a biofilm adhesion caused by bacterial and algal cell colonization leading to the settlement of macrofouling organisms [6-9].

Marine biofouling represents a global phenomenon generating undoubtedly profound economic and ecological problems that needs to be addressed vigorously. It affects almost any kind of submerged surface, including aquaculture systems, coastal electric power stations, various underwater constructions, and marine vessels [10-12]. It has been and remains a major issue for the shipping industry with an outstanding financial cost, mandating huge capital investments for its control and efficient management, often associated 
until recently with detrimental environmental effects. The attachment of microbial slimes, algae, and marine sessile organisms, such as barnacles and mussels, on the rough surfaces of ship hulls results in increased weight and hydrodynamic frictional resistance, accounting for a tremendous increase in fuel consumption, greenhouse gas emissions, dry-docking time, vessel maintenance, and marine transport cost [13-18].

Several antifouling methods have been developed over the years, with the most effective being based mainly on biocidal chemicals incorporated in coatings and paints. The antifouling organotin-based paints that have been widely applied, such as tributyltin (TBT), have been proven very effective in preventing fouling [19-22]. However, they are characterized by severe toxicity for marine life and therefore are nowadays prohibited worldwide by the International Maritime Organization (IMO) [23]. Their replacement by copper-based coatings and booster biocides, such as diuron, Irgarol 1051, SeaNine 211, and zinc pyrithione, failed to adequately address the issue of environmental impact [24], and most of them have already been banned by many European countries [25]. Inert, silicon-based and polymer-based coatings that were subsequently applied as an alternative approach have been proven inefficient since they are expensive, difficult to apply, and not durable enough to provide long-lasting hull protection, while the environmental impact of their additives still remains undetermined [26].

Concerning marine ecosystem and human health, an ecological approach is unquestionably the only way forward for antifouling technology $[27,28]$. The ideal candidate for biofouling control should be environmentally safe, providing maximum fouling protection. The solution for alternative, effective, non-toxic antifouling agents could be lying in the chemistry of marine natural products [29-33]. In the very competitive marine ecosystem, organisms, such as seaweeds, sponges, corals, and other invertebrates, have developed various chemical and biological defense mechanisms to protect their surfaces from fouling. Secondary metabolites (e.g., sulfated polyphenols, steroids, terpenoids, and alkaloids) and biopolymers have been reported to be involved in different interactions of marine life for the repellence, inhibition, and suppression of settlement and growth of fouling organisms [33]. Many isolated compounds from marine prokaryotes and eukaryotes have shown antifouling activity, fulfilling the U.S. Navy Program standards of $\mathrm{EC}_{50}$ values $<25.0 \mathrm{mg} / \mathrm{L}$, with actual $\mathrm{EC}_{50}$ values less than $5 \mathrm{mg} / \mathrm{L}$. Among them, macroalgal secondary metabolites have been regarded as non-toxic antifouling agents with great potential $[34,35]$.

In the framework of our research investigations, we have previously identified bromosphaerol (1), a brominated diterpene isolated from the red alga Sphaerococcus coronopifolius, as a promising agent with significant antifouling activity [36,37]. In these studies, bioassays conducted using larvae of the cirriped crustacean Amphibalanus (Balanus) amphitrite showed that bromosphaerol (1) exerted significant anti-settlement activity with an $\mathrm{EC}_{50}$ value of $0.23 \mathrm{mg} / \mathrm{L}$, combined with extremely low toxicity $\left(\mathrm{LC}_{50}>100 \mathrm{mg} / \mathrm{L}\right)$, resulting in an impressive therapeutic ratio $\left(\mathrm{TR}_{\mathrm{C}}=\mathrm{LC}_{50} / \mathrm{EC}_{50}\right)$ of 434.78 . The significant antifouling activity and low toxicity of bromosphaerol (1) motivated us to explore its chemistry, aiming to optimize its antifouling potential through the preparation of a number of analogs. Herein, we report the synthesis of a series of bromosphaerol derivatives, along with the evaluation of their antifouling activity.

\section{Results and Discussion}

In order to improve the antifouling potential of the brominated diterpene bromosphaerol (1), 15 structural analogs involving transformations at $\Delta^{1}$ double bond and positions C-11, C-16, and C-17 (2-16) were designed and synthesized (Figures 1 and S1-S46). Our strategy for obtaining initial structure-antifouling activity relationships for bromosphaerol involved (a) introducing polar groups at C-1 and/or C-2 (2-6 and 8), (b) removing the C-11 hydroxyl group (9 and 10), and (c) substituting C-2 with functional groups (ester and oxime), while the $\Delta^{1}$ double bond was repositioned to C-1-C-10 to allow for the generation of an extended conjugated system (7 and 11-16). 
<smiles>CC(C)C1(CBr)CC[C@]2(C)[C@H](Br)CC[C@@](C)(O)[C@@H]2[C@H]1CBr</smiles><smiles>CC(C)[C@H]1CC[C@@H](O)[C@]23C[C@](C)(O)CC[C@H](Br)[C@@]2(C)CC[C@]13CBr</smiles>

5<smiles>C=C1CC[C@@H](Br)[C@]2(C)CC[C@@]3(CBr)[C@@H](C=CC[C@@H]3C(C)C)[C@H]12</smiles>

9<smiles>[R20]N=C1C=C2[C@@H]3[C@](C)(CC[C@@]2(C)O)[C@H](Br)CC[C@]3(C)[C@H](C(C)C)C1</smiles>

$12 \mathrm{R}=\mathrm{H}$

$13 \mathrm{R}=\mathrm{Me}$<smiles>CC(C)[C@H]1CC2O[C@H]2[C@@H]2[C@@H]3[C@](C)(CC[C@]12CBr)[C@H](Br)CC[C@@]3(C)O</smiles>

2

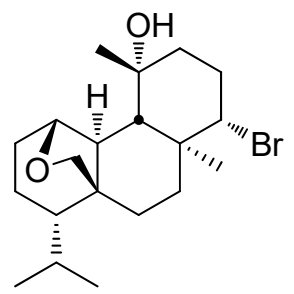

6<smiles>CC1=C2[C@H](C(C)C)CC=C[C@@H]2[C@@]2(C)CC[C@H](Br)C(CBr)(CBr)[C@H]12</smiles><smiles>CC(C)[C@H]1CC(=O)C=C2[C@H]3[C@](C)(CC[C@]21CBr)[C@@H](Br)CC[C@@]3(C)O</smiles>

7<smiles>CC(C)[C@H]1CCC(=O)[C@@H]2[C@H]3[C@](C)(CC[C@]12CBr)[C@@H](Br)CC[C@@]3(C)O</smiles>

4<smiles>CC(C)[C@H]1C[C@@H](Br)[C@H]2O[C@]3(C)CC[C@H](Br)[C@@]4(C)CC[C@]1(CBr)[C@H]2[C@H]43</smiles>

8
10<smiles>[R6]C(=O)CON=C1C=C2[C@H]3[C@](C)(CC[C@]2(CBr)[C@H](C(C)C)C1)[C@@H](Br)CC[C@@]3(C)O</smiles>

$14 \mathrm{R}=\mathrm{H}$

$15 \mathrm{R}=\mathrm{Me}$<smiles>CCOC(=O)C=C1C=C2[C@H]3[C@](C)(CC[C@]2(CBr)[C@H](C(C)C)C1)[C@@H](Br)CC[C@@]3(C)O</smiles>

11<smiles>CC(C)[C@H]1CC(=NOCCN(C)C)C=C2[C@H]3[C@](C)(CC[C@]21CBr)[C@@H](Br)CC[C@@]3(C)O</smiles>

16

Figure 1. Bromosphaerol (1) and its synthetic derivatives 2-16.

Initially, our synthetic efforts were focused on introducing an epoxide ring at the $\Delta^{1}$ double bond of $\mathbf{1}$. This was achieved using $p$-chloroperbenzoic acid in dichloromethane, which resulted in a mixture of the two diastereomeric epoxides $\mathbf{2}$ and $\mathbf{3}$ (Figure 2) in a 65:35 ratio and $75 \%$ overall yield, both of which were subsequently isolated in pure form. The configuration at the chiral centers $C-1$ and C-2 of 2 was deduced as $1 S, 2 R$ on the basis of NOE enhancements of $\mathrm{H}-1$ and $\mathrm{H}-2$ with $\mathrm{H}_{3}-19$ and $\mathrm{H}_{3}-20$, respectively.

Subsequently, we aimed at introducing a carbonyl functionality at C-1 or C-2. Therefore, bromosphaerol (1) was subjected to a hydroboration/oxidation sequence, using a borane tetrahydrofuran complex and sodium perborate, followed by pyridinium chlorochromate (PCC)-mediated oxidation of the generated alcohols. The above synthetic strategy resulted in a mixture of the ketone 4 and the precursor alcohol 5 due to incomplete oxidation, in a 1:0.7 ratio and a $41 \%$ yield. As a side product of the reaction, compound 6 was isolated in 45\% yield (Figure 2). Compound 6, bearing an oxygen bridge between C-1 and C-17, was formed during the hydroboration step through an $\mathrm{SN}_{2}$ nucleophilic attack of the C-1 epimer of 5 on the brominated carbon C-17 and could not be oxidized further upon PCC treatment. 


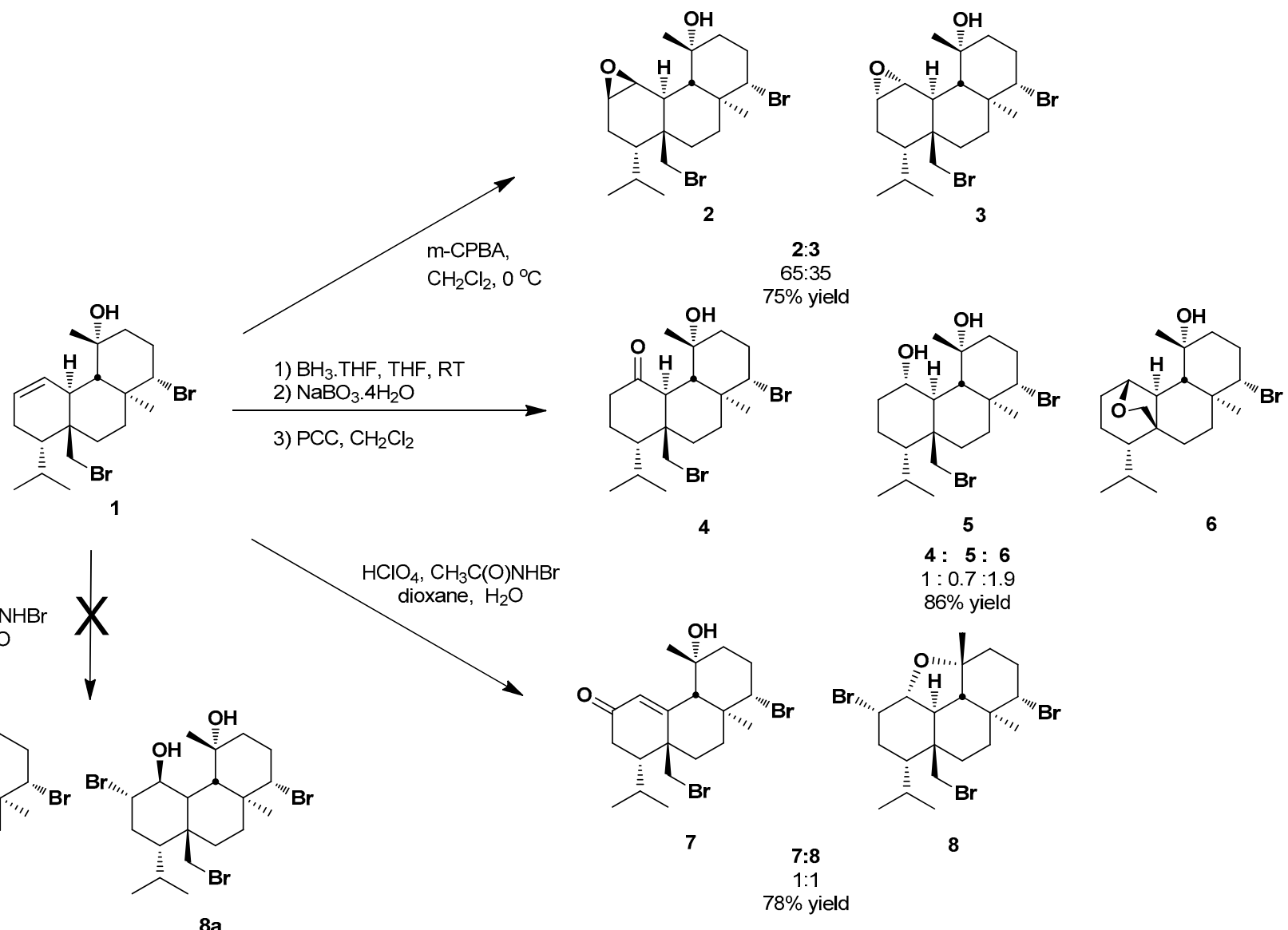

Figure 2. Synthesis of bromosphaerol derivatives $\mathbf{2}-\mathbf{8}$.

In a next step, we attempted to synthesize the bromohydrin derivatives $7 \mathbf{a}$ and $8 \mathbf{a}$ of 1 through treatment with $N$-bromoacetamide in the presence of perchloric acid in a mixture of water/dioxane. Instead, we isolated the $\alpha, \beta$-unsaturated ketone 7 , and the C-2 brominated compound 8 (Figure 2). Compound 7 could be generated from the intermediate bromohydrin 7a through oxidation of the C-2 alcohol followed by E2 elimination of the $\mathrm{C}-1$ bromine and subsequent formation of the C-1-C-10 double bond. Compound 7 was also isolated as the single product from the oxidation of the mixture of the diastereomeric epoxides 2 and 3 using Jones reagent. On the other hand, hypobromous acid generated in situ from NBA and perchloric acid reacted, with the $\Delta^{1}$ double bond affording the $2 \alpha$-bromo C-1 carbocation intermediate, which reacted further with the C-11 alcohol to produce the corresponding compound 8 bearing a bromine atom at C-2 and an additional fused furan ring composed of C-1, C-10, C-9, and C-11. The stereochemistry at the chiral centers C-1, C-2, and C-11 was deduced as $1 R, 2 S, 11 R$ on the basis of the cross-peaks observed in the NOESY spectrum, as well as the measured coupling constants. In particular, the coupling constant measured between $\mathrm{H}-1$ and $\mathrm{H}-10(\mathrm{~J}=11.8 \mathrm{~Hz})$ allowed for the determination of the configuration of the oxygenated $\mathrm{H}-1$ as axial, whereas the coupling constant measured between $\mathrm{H}-1$ and $\mathrm{H}-2(\mathrm{~J}=3.2 \mathrm{~Hz})$ allowed for the determination of the configuration of the bromomethine $\mathrm{H}-2$ as equatorial. Additionally, the NOE correlations of $\mathrm{H}-1$ with $\mathrm{H}-9, \mathrm{H}_{3}-11$, and $\mathrm{H}-17 \mathrm{~b}$, as well as of $\mathrm{H}_{3}-11$ with $\mathrm{H}-9$ and $\mathrm{H}-14$, dictated that the stereochemistry at C-11 remained as $R$. This proposed mechanism is supported by the relative cis stereochemistry of $\mathrm{H}-1$ and $\mathrm{H}-2$ in compound 8. In the case of the formation of a bromonium ion intermediate, an anti-addition would be expected, resulting in a trans relative stereochemistry of $\mathrm{H}-1$ and $\mathrm{H}-2$.

Furthermore, the regiomeric olefins $\mathbf{9}$ and $\mathbf{1 0}$ were formed in $70 \%$ and $10 \%$ yield, respectively, by an elimination reaction of the hydroxyl group at C-11 upon treatment 
of 1 with trimethylsilyl trifluoromethanesulfonate in the presence of acetic anhydride (Figure 3). Compounds 9 and 10, named bromosphaerenes B and A, respectively, were previously isolated from $S$. coronopifolius by Fattorusso et al. (1983), and their structures were confirmed through dehydration of bromosphaerol (1) upon heating at $100{ }^{\circ} \mathrm{C}$ with phosphorus oxychloride-pyridine to afford bromosphaerene A (10) as the major product [38]. In contrast, our synthetic method provided preferentially bromosphaerene B (9).

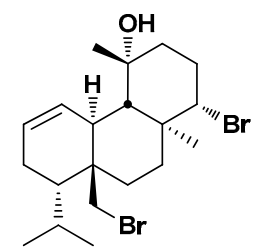

1

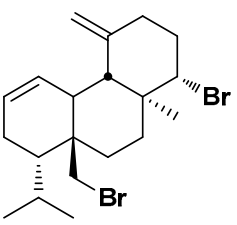

$9(70 \%$ yield $)$

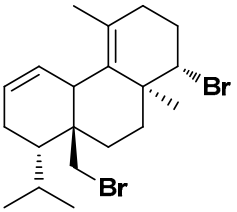

$10(10 \%$ yield $)$

Figure 3. Synthesis of bromosphaerol derivatives $\mathbf{9}$ and $\mathbf{1 0 .}$

The $\alpha, \beta$-unsaturated ketone 7 was proven to be a valuable synthetic intermediate toward the synthesis of a number of analogs. Thus, the Horner-Wadsworth-Emmons reaction of $\mathbf{7}$ with triethyl phosphonoacetate afforded the unsaturated ester $\mathbf{1 1}$ in $90 \%$ yield (Figure 4), as a mixture of $E, Z$ geometric isomers (in a 6 to 4 ratio). Finally, a series of oxime derivatives (12-16) were obtained in good to excellent yields (56 to 98\%), using ketone 7 and various substituted alkoxyamines in the presence of pyridine (Figure 4).

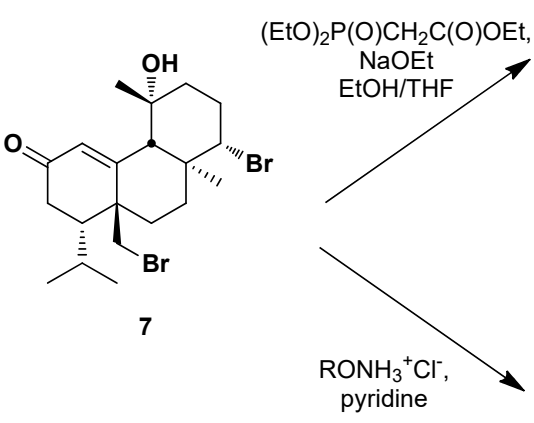

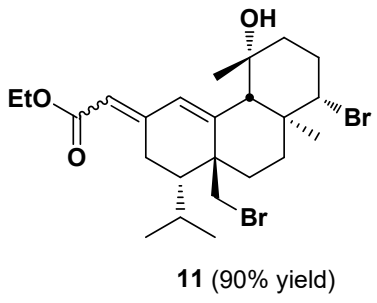<smiles>[R]ON=C1C=C2CC[C@]3(C)[C@@H](Br)CC[C@](C)([C@@H](C(C)C)C1)[C@H]23</smiles>

$12 \mathrm{R}=\mathrm{H}(95 \%$ yield $)$

$13 \mathrm{R}=\mathrm{CH}_{3}(98 \%$ yield)

$14 \mathrm{R}=\mathrm{CH}_{2} \mathrm{COOH}$ (98\% yield)

$15 \mathrm{R}=\mathrm{CH}_{2} \mathrm{COOCH}_{3}$ (56\% yield)

$16 \mathrm{R}=\left(\mathrm{CH}_{2}\right)_{2} \mathrm{~N}\left(\mathrm{CH}_{3}\right)_{2}(81 \%$ yield $)$

Figure 4. Synthesis of bromosphaerol derivatives 11-16.

The results of the settlement inhibition assay performed on cypris larvae of $A$. amphitrite and the mortality test carried out on the stage II nauplii of the same model organism for bromosphaerol derivatives $\mathbf{2 , 4}$, and 6-16 are shown in Table 1, summarizing the $\mathrm{EC}_{50}$ values obtained for cyprids settlement test (after $72 \mathrm{~h}$ ), the $\mathrm{LC}_{50}$ values obtained for cypris larvae mortality (after $72 \mathrm{~h}$ ), and the $\mathrm{LC}_{50}$ values of naupliar mortality (after $48 \mathrm{~h}$ ). According to the guidelines of the U.S. Navy Program that require an $\mathrm{EC}_{50}$ (settlement inhibition) value lower than $25 \mathrm{mg}$ / L for a compound to be considered as a promising natural antifoulant, 9 of the 13 derivatives tested in this study meet this requirement. In particular, compounds 2, 4, 6, and 7, which bear an oxygen moiety at C-1 or C-2, exhibit similar $\mathrm{EC}_{50}$ values ranging from 10.44 to $8.75 \mathrm{mg} / \mathrm{L}$. Conversely, the introduction of a bromine substituent at C-2 abolishes activity. This is also the case for the $\alpha, \beta$-unsaturated ester analog 11. Interestingly, derivative 9 , in which the hydroxyl at C-11 was eliminated to form 
the exocyclic double bond, exhibited potent antifouling activity with an $\mathrm{EC}_{50}<0.5 \mathrm{mg} / \mathrm{L}$. Surprisingly, the endocyclic elimination congener 10 was less potent $\left(\mathrm{EC}_{50}=3.87 \mathrm{mg} / \mathrm{L}\right)$. Furthermore, the activity of derivatives 12-16 was influenced significantly by the nature of the oxime functionality. Thus, the unsubstituted oxime compound $\mathbf{1 2}$ and the carboxy oxime derivative 14 were inactive, in contrast to the methoxy oxime analog 13 and the methyl ester congener of 14, compound 15, that possess $\mathrm{EC}_{50}<0.5 \mathrm{mg} / \mathrm{L}$. This is also the case for dimethylaminoethyl oxime derivative 16 showing $\mathrm{EC}_{50}<0.5 \mathrm{mg} / \mathrm{L}$. Thus, analogs $9,13,15$, and 16 exhibit very promising antifouling efficacy.

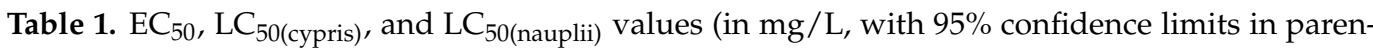
theses) for cypris larvae settlement inhibition, cypris larvae mortality, and naupliar mortality of Amphibalanus amphitrite after exposure for 72,72 , and $48 \mathrm{~h}$, respectively, to bromosphaerol derivatives $\mathbf{2 , 4}$, and 6-16, as well as therapeutic ratios for bromosphaerol derivatives $\mathbf{2 , 4}$, and 6-16 calculated against both $\mathrm{LC}_{50 \text { (nauplii) }}$ values from naupliar toxicity test $\left(\mathrm{TR}_{\mathrm{N}}\right)$ and $\mathrm{LC}_{50 \text { (cypris) }}$ values from cyprids toxicity assay $\left(\mathrm{TR}_{\mathrm{C}}\right)$.

\begin{tabular}{|c|c|c|c|c|c|}
\hline Compounds & $\begin{array}{c}\mathrm{EC}_{50}(72 \mathrm{~h}) \\
\text { Cypris Larvae } \\
\text { Settlement Inhibition }\end{array}$ & $\begin{array}{c}\mathrm{LC}_{50 \text { (cypris) }}(72 \mathrm{~h}) \\
\text { Cypris Larvae } \\
\text { Mortality }\end{array}$ & $\begin{array}{c}\mathrm{LC}_{50 \text { (nauplii) }}(48 \mathrm{~h}) \\
\text { Naupliar } \\
\text { Mortality }\end{array}$ & $\underset{\left(\mathrm{LC}_{50(\text { nauplii) }} / \mathrm{EC}_{50}\right)}{\mathrm{TR}_{\mathrm{N}}}$ & $\begin{array}{c}\mathrm{TR}_{\mathrm{C}} \\
\left(\mathrm{LC}_{50 \text { (cypris) }} / \mathrm{EC}_{50}\right)\end{array}$ \\
\hline 1 & $0.23(0.17-0.30)$ & $>100$ & $3.63(3.05-4.33)$ & 15.78 & 434.78 \\
\hline 2 & $10.44^{+}$ & $25.2^{\dagger}$ & $2.75(2.47-3.07)$ & 0.26 & 2.39 \\
\hline 4 & $7.19(4.57-11.3)$ & $>50$ & $1.27^{\dagger}$ & 0.17 & 6.95 \\
\hline 6 & $7.53(5.82-9.73)$ & $10.2^{\dagger}$ & $7.57(6.10-9.38)$ & 1.00 & 1.32 \\
\hline 7 & $8.75(6.75-11.34)$ & $>50$ & $11.53(9.53-13.95)$ & 1.31 & $>5.71$ \\
\hline 8 & $>50$ & $>50$ & $>50$ & n.d. $\ddagger$ & n.d. $\ddagger$ \\
\hline 9 & $<0.5$ & $>50$ & $1.19^{\dagger}$ & 2.38 & $>100$ \\
\hline 10 & $3.87^{\dagger}$ & $>50$ & $2.31^{\dagger}$ & 0.59 & 12.90 \\
\hline 11 & $>50$ & $>50$ & $21.64(16.57-28.28)$ & n.d. $\ddagger$ & n.d. $\ddagger$ \\
\hline 12 & $>50$ & $>50$ & $1.21^{\dagger}$ & n.d. $\ddagger$ & n.d. $\ddagger$ \\
\hline 13 & $<0.5$ & $>50$ & $1.26^{+}$ & 2.52 & $>100$ \\
\hline 14 & $>50$ & $>50$ & $>50$ & n.d. $\ddagger$ & n.d. $\ddagger$ \\
\hline 15 & $<0.5$ & $12.5^{\dagger}$ & $1.81^{\dagger}$ & 3.62 & 25.00 \\
\hline 16 & $<0.5$ & $2.7^{+}$ & $1.36^{\dagger}$ & 2.72 & 5.40 \\
\hline
\end{tabular}

Concerning the toxicity observed on cypris larvae, the $\mathrm{LC}_{50}(72 \mathrm{~h})$ values are $>50 \mathrm{mg} / \mathrm{L}$ for derivatives $\mathbf{9}$ and $\mathbf{1 3}$, while $\mathbf{1 5}$ and $\mathbf{1 6}$ demonstrated substantial toxicity towards this larval stage ( $\mathrm{LC}_{50}$ values of 2.7 and $12.5 \mathrm{mg} / \mathrm{L}$, respectively). This was also observed for the epoxy derivative 2 and the tetrahydrofuranyl analog 6 , possessing $\mathrm{LC}_{50}$ values of 25.2 and $10.2 \mathrm{mg} / \mathrm{L}$, respectively. Gratifyingly, all the other compounds were not toxic against cypris larvae with $\mathrm{LC}_{50}$ values $>50 \mathrm{mg} / \mathrm{L}$. However, all synthetic analogs displayed quite high toxicity towards the naupliar stage, with $\mathrm{LC}_{50}(48 \mathrm{~h})$ values between 1.19 and $21.64 \mathrm{mg} / \mathrm{L}$ with the exception of the inactive 8 and 14 demonstrating $\mathrm{LC}_{50}$ values $>50 \mathrm{mg} / \mathrm{L}$.

As previously reported [36], although the therapeutic ratio (TR) is traditionally calculated by taking into account naupliar mortality, measuring mortality on the same larval stage on which settlement is evaluated (cypris larvae, competent larval stage) is also important since TR should actually indicate whether the mechanism of settlement inhibition is based on a toxic effect. In addition, the $\mathrm{LC}_{50}$ on nauplii can be considered as a good index of toxicity against non-target organisms since nauplii are considered as a representative zooplankton organism. It is evident that naupliar response to the tested bromosphaerol 
derivatives is very different from that of cyprids; indeed, naupliar mortality occurs at lower concentrations than mortality of cyprids. Table 1 reports the TR values calculated taking into account both nauplii $\left(\mathrm{TR}_{\mathrm{N}}\right)$ and cyprids $\left(\mathrm{TR}_{\mathrm{C}}\right)$ mortality values. High $\mathrm{TR}$ values indicate a low toxicity anti-settlement mechanism for the tested compounds. For derivatives showing promising $\mathrm{EC}_{50}$ values $(\mathbf{9}, \mathbf{1 3}, \mathbf{1 5}$, and $\mathbf{1 6})$, the $\mathrm{TR}_{\mathrm{N}}$ is quite low (ranging from 2.38 to 3.62), while higher values are observed for $\mathrm{TR}_{C}$, especially for derivatives $\mathbf{9}$ and $\mathbf{1 3}$ $(>100)$. Concerning cyprids mortality, $\mathbf{9}$ and $\mathbf{1 3}$ showed $\mathrm{LC}_{50 \text { (cypris) }}$ values higher than the maximum tested concentration $(50 \mathrm{mg} / \mathrm{L})$. Looking at the two more promising in terms of antifouling efficacy derivatives ( 9 and 13 ), the $\mathrm{TR}_{\mathrm{N}}$ values are much lower than the $\mathrm{TR}_{\mathrm{C}}$ values. Taking into account only the $\mathrm{TR}_{\mathrm{N}}$ values, we can assert that analogs 9 and 13 are characterized by good antifouling properties $\left(\mathrm{EC}_{50}<0.5 \mathrm{mg} / \mathrm{L}\right)$ but may exhibit some toxicity against non-target organisms, as mentioned above. Conversely, considering the $\mathrm{TR}_{\mathrm{C}}$ values (>100) of $\mathbf{9}$ and $\mathbf{1 3}$, both derivatives can be considered as well-performing antifoulants, exerting their activity through a non-toxic mechanism.

\section{Materials and Methods}

\subsection{General Experimental Procedures}

1D and 2D NMR spectra were recorded on Bruker DRX 400 (Bruker BioSpin GmbH, Rheinstetten, Germany) and Varian 300 and Varian 600 (Varian, Inc., Palo Alto, CA, USA) spectrometers, using standard Bruker or Varian pulse sequences. Chemical shifts internally referenced to residual solvent signals are given on a $\delta(\mathrm{ppm})$ scale. High-resolution ESI and APCI mass spectra were measured on a Thermo Scientific LTQ Orbitrap Velos mass spectrometer (ThermoFisher Scientific, Bremen, Germany). Column chromatography separations were performed with Kieselgel Si 60 (Merck, Darmstadt, Germany). HPLC separations were conducted on a CECIL 1100 Series liquid chromatography pump (Cecil Instruments Ltd., Cambridge, UK) equipped with a GBC LC-1240 refractive index detector (GBC Scientific Equipment, Braeside, VIC, Australia), using a $250 \mathrm{~mm} \times 22 \mathrm{~mm}$ i.d. Techsil 10 ODS column (Wellington House, Cheshire, UK) for reversed-phase HPLC or a $250 \mathrm{~mm}$ $\times 10 \mathrm{~mm}$ i.d. Kromasil 100-10-SIL (Akzonobel, Eka Chemicals AB, Separation Products, Bohus, Sweden) for normal-phase HPLC. TLC was performed on Kieselgel $60 \mathrm{~F}_{254}(0.2 \mathrm{~mm})$ precoated aluminum or glass plates (Merck, Darmstadt, Germany), and spots were visualized after spraying with $\mathrm{H}_{2} \mathrm{SO}_{4}$ in $\mathrm{MeOH}(20 \% v / v)$ reagent and heating at $100{ }^{\circ} \mathrm{C}$ for $1 \mathrm{~min}$.

\subsection{Biological Material}

Specimens of S. coronopifolius were collected by scuba diving in the bay of Palaiokastritsa, Corfu, Greece, at a depth of 15-40 m in August 2013. A voucher specimen of the alga has been deposited at the Herbarium of the Section of Pharmacognosy and Chemistry of Natural Products, Department of Pharmacy, National and Kapodistrian University of Athens (ATPH/MP0226).

\subsection{Extraction and Isolation}

Air-dried algal tissues ( $0.5 \mathrm{~kg}$ dry weight) were exhaustively extracted with mixtures of $\mathrm{CH}_{2} \mathrm{Cl}_{2} / \mathrm{MeOH}$ (3:1) at room temperature. Evaporation of the solvents in vacuo afforded a dark green oily residue ( $18 \mathrm{~g}$ ) that was subjected to vacuum column chromatography over silica gel, using cHex with increasing amounts of EtOAc and subsequently EtOAc with increasing amounts of $\mathrm{MeOH}$ as the mobile phase to yield 15 fractions (1-15). Fraction 3 (cHex/EtOAc 80:20, 10.9 g) was subjected to preparative reversed-phase HPLC using $\mathrm{MeOH} 100 \%$ as the mobile phase to afford sphaerococcenol A $(2.1 \mathrm{~g})$ and bromosphaerol (1) $(4.45 \mathrm{~g})$. 


\subsection{Synthesis of Analogs of Bromosphaerol}

3.4.1. Synthesis of Analogs 2 and 3

To a stirred solution of bromosphaerol (1) $(19.3 \mathrm{mg}, 0.043 \mathrm{mmol})$ in anhydrous $\mathrm{CH}_{2} \mathrm{Cl}_{2}$ $(0.8 \mathrm{~mL})$, a solution of $m$-chloroperoxybenzoic acid $77 \%(14.45 \mathrm{mg}, 0.065 \mathrm{mmol})$ in $\mathrm{CH}_{2} \mathrm{Cl}_{2}$ $(0.8 \mathrm{~mL})$ was added dropwise at $0{ }^{\circ} \mathrm{C}$, and the reaction mixture was stirred for $2 \mathrm{~h}$ at $25{ }^{\circ} \mathrm{C}$. Upon completion of the reaction (monitored by TLC), saturated aqueous $\mathrm{Na}_{2} \mathrm{SO}_{3}$ solution $(2.0 \mathrm{~mL})$ was added. The $\mathrm{pH}$ was adjusted to 7 by the addition of $5 \%$ aqueous $\mathrm{NaHCO}_{3}$ solution, and the reaction mixture was extracted with $\mathrm{CH}_{2} \mathrm{Cl}_{2}(3 \times 15 \mathrm{~mL})$. The combined organic layers were dried over anhydrous $\mathrm{Na}_{2} \mathrm{SO}_{4}$, concentrated under reduced pressure, dried in vacuo to afford a mixture of the diastereomeric epoxides $\mathbf{2}$ and $\mathbf{3}$ in a 65:35 ratio (15 mg, 75\%), which was subjected to flash column chromatography (elution system: petroleum ether $40-65^{\circ} \mathrm{C} /$ acetone, $40: 60$ to $95: 10$ ) and subsequently normal-phase HPLC using cHex/EtOAc $(75: 25)$ as eluent to afford $\mathbf{2}(9.5 \mathrm{mg})$ and $\mathbf{3}(3.8 \mathrm{mg})$ in pure form.

Compound 2: Gummy solid; ${ }^{1} \mathrm{H}$ NMR $\left(600 \mathrm{MHz}, \mathrm{CDCl}_{3}\right) \delta 0.94(3 \mathrm{H}, \mathrm{d}, J=6.9 \mathrm{~Hz}$, $\left.\mathrm{H}_{3}-19\right), 0.97\left(3 \mathrm{H}, \mathrm{d}, J=6.9 \mathrm{~Hz}, \mathrm{H}_{3}-20\right), 1.22(1 \mathrm{H}, \mathrm{m}, \mathrm{H}-7 \mathrm{~b}), 1.31\left(3 \mathrm{H}, \mathrm{s}, \mathrm{H}_{3}-15\right), 1.42(3 \mathrm{H}, \mathrm{s}$, $\left.\mathrm{H}_{3}-16\right), 1.46(1 \mathrm{H}, \mathrm{m}, \mathrm{H}-6 \mathrm{~b}), 1.59(1 \mathrm{H}, \mathrm{d}, J=10.8 \mathrm{~Hz}, \mathrm{H}-9), 1.66(1 \mathrm{H}, \mathrm{m}, \mathrm{H}-4), 1.68(1 \mathrm{H}, \mathrm{m}$, H-12b), $1.73(1 \mathrm{H}, \mathrm{m}, \mathrm{H}-6 \mathrm{a}), 1.74$ (1H, m, H-12a), 1.75 (1H, m, H-7a), 1.87 (1H, ddd, J = 16.6, 6.4, $1.0 \mathrm{~Hz}, \mathrm{H}-3 \mathrm{~b}), 1.97(1 \mathrm{H}, \mathrm{m}, \mathrm{H}-13 \beta), 1.99(1 \mathrm{H}, \mathrm{m}, \mathrm{H}-3 \mathrm{a}), 2.04(1 \mathrm{H}, \mathrm{qd}, J=6.9,1.6 \mathrm{~Hz}$, $\mathrm{H}-18), 2.42(1 \mathrm{H}, \mathrm{qd}, J=13.0,4.3 \mathrm{~Hz}, \mathrm{H}-13 \alpha), 2.72(1 \mathrm{H}, \mathrm{dd}, J=10.8,2.0 \mathrm{~Hz}, \mathrm{H}-10), 3.26(1 \mathrm{H}$, $\mathrm{m}, \mathrm{H}-2), 3.45(1 \mathrm{H}, \mathrm{dd}, J=4.3,2.0 \mathrm{~Hz}, \mathrm{H}-1), 3.76(1 \mathrm{H}, \mathrm{d}, J=10.9 \mathrm{~Hz}, \mathrm{H}-17 \mathrm{~b}), 3.98(1 \mathrm{H}, \mathrm{dd}$, $J=13.0,3.5 \mathrm{~Hz}, \mathrm{H}-14), 4.21(1 \mathrm{H}, \mathrm{dd}, J=10.9,1.9 \mathrm{~Hz}, \mathrm{H}-17 \mathrm{a}) ;{ }^{13} \mathrm{C} \mathrm{NMR}\left(75 \mathrm{MHz}, \mathrm{CDCl}_{3}\right) \delta$ 14.0 (C-15), 19.9 (C-3), 20.8 (C-20), 24.9 (C-18), 25.7 (C-6), 25.8 (C-19), 30.1 (C-13), 33.3 (C-16), 35.9 (C-10), 36.2 (C-7), 39.4 (C-17), 41.0 (C-8), 41.8 (C-5), 42.7 (C-4), 46.0 (C-12), 48.8 (C-9), 54.5 (C-2), 55.1 (C-1), 68.3 (C-14), 72.6 (C-11); HR-ESIMS m/z 485.0662 [M+Na] ${ }^{+}$(calcd. for $\mathrm{C}_{20} \mathrm{H}_{32}{ }^{79} \mathrm{Br}_{2} \mathrm{O}_{2} \mathrm{Na}$, 485.0661).

Compound 3: Gummy solid; ${ }^{1} \mathrm{H}$ NMR $\left(400 \mathrm{MHz}, \mathrm{CDCl}_{3}\right) \delta 0.85(3 \mathrm{H}, \mathrm{d}, J=6.8 \mathrm{~Hz}$, $\left.\mathrm{H}_{3}-19\right), 0.94\left(3 \mathrm{H}, \mathrm{d}, J=6.8 \mathrm{~Hz}, \mathrm{H}_{3}-20\right), 1.13(1 \mathrm{H}, \mathrm{td}, J=13.9,3.0 \mathrm{~Hz}, \mathrm{H}-7 \mathrm{~b}), 1.18(3 \mathrm{H}, \mathrm{s}$, $\left.\mathrm{H}_{3}-15\right), 1.40(1 \mathrm{H}, \mathrm{ddd}, J=14.6,12.3,5.2 \mathrm{~Hz}, \mathrm{H}-3 \mathrm{~b}), 1.45\left(3 \mathrm{H}, \mathrm{s}, \mathrm{H}_{3}-16\right), 1.52(1 \mathrm{H}, \mathrm{d}, J=11.8$ $\mathrm{Hz}, \mathrm{H}-9), 1.64$ (1H, m, H-12b), 1.67 (1H, m, H-6b), 1.71 (1H, m, H-12a), 1.80 (1H, m, H-4), $1.85(1 \mathrm{H}, \mathrm{m}, \mathrm{H}-10), 1.86(1 \mathrm{H}, \mathrm{m}, \mathrm{H}-7 \mathrm{a}), 1.88(1 \mathrm{H}, \mathrm{m}, \mathrm{H}-6 \mathrm{a}), 2.00(1 \mathrm{H}, \mathrm{m}, \mathrm{H}-18), 2.03(1 \mathrm{H}, \mathrm{m}$, $\mathrm{H}-13 \beta), 2.05(1 \mathrm{H}, \mathrm{m}, \mathrm{H}-3 \mathrm{a}), 2.49(1 \mathrm{H}, \mathrm{qd}, J=13.0,4.8 \mathrm{~Hz}, \mathrm{H}-13 \alpha), 3.06(1 \mathrm{H}, \mathrm{dd}, J=6.6,4.8$ $\mathrm{Hz}, \mathrm{H}-1), 3.37(1 \mathrm{H}, \mathrm{m}, \mathrm{H}-2), 3.38(1 \mathrm{H}, \mathrm{d}, J=10.1 \mathrm{~Hz}, \mathrm{H}-17 \mathrm{~b}), 3.86(1 \mathrm{H}, \mathrm{d}, J=10.1 \mathrm{~Hz}, \mathrm{H}-17 \mathrm{a})$, $3.98(1 \mathrm{H}, \mathrm{dd}, J=13.0,4.0 \mathrm{~Hz}, \mathrm{H}-14) ;{ }^{13} \mathrm{C} \mathrm{NMR}\left(400 \mathrm{MHz}, \mathrm{CDCl}_{3}\right.$, determined through HMBC correlations) $\delta 15.7$ (C-15), 18.5 (C-19), 22.1 (C-3), 23.4 (C-20), 24.7 (C-6), 27.0 (C-18), 30.7 (C-13), 33.2 (C-16), 36.6 (C-7), 40.6 (C-8), 41.1 (C-10), 42.1 (C-5), 43.8 (C-17), 44.2 (C-12), 45.4 (C-4), 50.7 (C-9), 53.9 (C-2), 54.3 (C-1), 67.7 (C-14), 72.7 (C-11); HR-ESIMS m/z 485.0662 $[\mathrm{M}+\mathrm{Na}]^{+}$(calcd. for $\mathrm{C}_{20} \mathrm{H}_{32}{ }^{79} \mathrm{Br}_{2} \mathrm{O}_{2} \mathrm{Na}, 485.0661$ ).

\subsubsection{Synthesis of Analogs 4-6}

To a stirred solution of bromosphaerol (1) $(63 \mathrm{mg}, 0.14 \mathrm{mmol})$ in anhydrous THF $(1.2 \mathrm{~mL})$, a $\mathrm{BH}_{3}$.THF complex solution (1M in THF) $(0.42 \mathrm{~mL}, 0.422 \mathrm{mmol})$ was added dropwise at $-10^{\circ} \mathrm{C}$, and the reaction mixture was stirred for $3 \mathrm{~h}$ at $25^{\circ} \mathrm{C}$. Subsequently, water $(0.5 \mathrm{~mL})$ was added dropwise, and the resulting mixture was stirred for $15 \mathrm{~min}$ at $25{ }^{\circ} \mathrm{C}$. Following that, $\mathrm{NaBO}_{3} .4 \mathrm{H}_{2} \mathrm{O}(43 \mathrm{mg}, 0.28 \mathrm{mmol})$ was added, and the mixture was stirred for $12 \mathrm{~h}$ at $25^{\circ} \mathrm{C}$. The precipitated solid was filtered off, washed with THF, and discarded. Subsequently, solid sodium chloride was added to the filtrate, and the mixture was extracted with EtOAc $(3 \times 20 \mathrm{~mL})$. The combined organic layers were dried over anhydrous $\mathrm{Na}_{2} \mathrm{SO}_{4}$ and concentrated under reduced pressure. The residue was dissolved in anhydrous $\mathrm{CH}_{2} \mathrm{Cl}_{2}(2.9 \mathrm{~mL}), \mathrm{PCC}(67 \mathrm{mg}, 0.31 \mathrm{mmol})$ was added, and the resulting mixture was stirred at $25{ }^{\circ} \mathrm{C}$ for $2 \mathrm{~h}$. The reaction mixture was diluted with $\mathrm{CH}_{2} \mathrm{Cl}_{2}$ $(10 \mathrm{~mL})$, and the mixture was filtered through a pad of celite and silica gel (1:1). The solids were washed with $\mathrm{CH}_{2} \mathrm{Cl}_{2}(50 \mathrm{~mL})$, the filtrate was evaporated in vacuo, and the residue was purified by flash column chromatography (elution system: petroleum ether $40-65{ }^{\circ} \mathrm{C} /$ acetone, $\left.90: 10\right)$ to afford $6(25 \mathrm{mg}, 45 \%$ yield) and a mixture of 4 and 5 in a 1:0.7 
ratio (27 $\mathrm{mg}$, 41\% yield) that was subsequently subjected to normal-phase HPLC using cHex/EtOAc (50:50) as eluent to yield $4(11.1 \mathrm{mg})$ and $5(6.7 \mathrm{mg})$ in pure form.

Compound 4: Gummy solid; ${ }^{1} \mathrm{H}$ NMR $\left(600 \mathrm{MHz}, \mathrm{CDCl}_{3}\right) \delta 0.88(3 \mathrm{H}, \mathrm{d}, J=6.9 \mathrm{~Hz}$, $\left.\mathrm{H}_{3}-19\right), 0.97\left(3 \mathrm{H}, \mathrm{d}, J=6.9 \mathrm{~Hz}, \mathrm{H}_{3}-20\right), 1.24(1 \mathrm{H}, \mathrm{m}, \mathrm{H}-7 \mathrm{~b}), 1.28\left(3 \mathrm{H}, \mathrm{s}, \mathrm{H}_{3}-15\right), 1.31(3 \mathrm{H}, \mathrm{s}$, $\left.\mathrm{H}_{3}-16\right), 1.42(1 \mathrm{H}, \mathrm{d}, \mathrm{J}=10.6 \mathrm{~Hz}, \mathrm{H}-9), 1.63$ (1H, m, H-12b), 1.67 (1H, m, H-6b), 1.69 (1H, m, H-12a), 1.87 (1H, m, H-6a), 1.93 (1H, m, H-7a), 1.97 (1H, m, H-13ß), 2.04 (1H, ddd, J = 6.6, 4.2, 2.2 Hz, H-4), 2.13 (1H, m, H-18), 2.31 (1H, m, H-3b), 2.33 (1H, m, H-2b), 2.41 (1H, m, H-13 $), 2.47$ (1H, m, H-3a), 2.84 (1H, m, H-2a), 2.87 (1H, d, J = 10.6 Hz, H-10), 3.65 (1H, $\mathrm{dd}, J=11.0,1.8 \mathrm{~Hz}, \mathrm{H}-17 \mathrm{~b}), 3.91(1 \mathrm{H}, \mathrm{d}, J=11.0 \mathrm{~Hz}, \mathrm{H}-17 \mathrm{a}), 3.95(1 \mathrm{H}, \mathrm{dd}, J=12.6,3.7$ $\mathrm{Hz}, \mathrm{H}-14) ;{ }^{13} \mathrm{C}$ NMR (400 MHz, $\mathrm{CDCl}_{3}$, determined through HMBC correlations) $\delta 14.2$ (C-15), 19.6 (C-19), 24.9 (C-6), 25.0 (C-20), 26.5 (C-18), 30.0 (C-13), 34.8 (C-16), 36.3 (C-7), 36.2 (C-3), 36.5 (C-10), 38.3 (C-17), 40.9 (C-5), 41.0 (C-8), 44.0 (C-2), 44.1 (C-4), 46.2 (C-12), 51.8 (C-9), 67.9 (C-14), 72.5 (C-11), 212.1 (C-1); HR-ESIMS m/z 485.0663 [M+Na] ${ }^{+}$(calcd. for $^{-}$ $\left.\mathrm{C}_{20} \mathrm{H}_{32}{ }^{79} \mathrm{Br}_{2} \mathrm{O}_{2} \mathrm{Na}, 485.0661\right)$.

Compound 5: Gummy solid; ${ }^{1} \mathrm{H}$ NMR $\left(600 \mathrm{MHz}, \mathrm{CDCl}_{3}\right) \delta 1.02(3 \mathrm{H}, \mathrm{d}, J=6.7 \mathrm{~Hz}$, $\left.\mathrm{H}_{3}-20\right), 1.05\left(3 \mathrm{H}, \mathrm{d}, J=6.7 \mathrm{~Hz}, \mathrm{H}_{3}-19\right), 1.22(1 \mathrm{H}, \mathrm{m}, \mathrm{H}-7 \mathrm{~b}), 1.32\left(3 \mathrm{H}, \mathrm{s}, \mathrm{H}_{3}-15\right), 1.38(3 \mathrm{H}, \mathrm{s}$, $\left.\mathrm{H}_{3}-16\right), 1.50$ (1H, m, H-3b), 1.53 (1H, m, H-2b), 1.59 (1H, m, H-12b), 1.60 (1H, m, H-6b), 1.61 $(1 \mathrm{H}, \mathrm{d}, J=10.1 \mathrm{~Hz}, \mathrm{H}-9), 1.67(1 \mathrm{H}, \mathrm{m}, \mathrm{H}-3 \mathrm{a}), 1.74(1 \mathrm{H}, \mathrm{m}, \mathrm{H}-4), 1.76$ (1H, m, H-6a), 1.79 (1H, m, H-12a), 1.83 (1H, m, H-7a), 1.92 (1H, m, H-13ß), 1.93 (1H, m, H-2a), 1.98 (1H, m, H-18), $2.29(1 \mathrm{H}, \mathrm{t}, J=10.1 \mathrm{~Hz}, \mathrm{H}-10), 2.44(1 \mathrm{H}, \mathrm{qd}, J=13.2,3.7 \mathrm{~Hz}, \mathrm{H}-13 \alpha), 3.49(1 \mathrm{H}, \mathrm{dd}, J=10.6,1.4$ Hz, H-17b), 3.97 (1H, d, J = 10.6 Hz, H-17a), 3.99 (1H, m, H-14), 4.00 (1H, m, H-1); ${ }^{13} \mathrm{C}$ NMR $\left(400 \mathrm{MHz}, \mathrm{CDCl}_{3}\right.$, determined through $\mathrm{HMBC}$ correlations) $\delta 14.4(\mathrm{C}-15), 18.7(\mathrm{C}-3), 21.1$ (C-19), 25.3 (C-20), 26.4 (C-18), 27.6 (C-6), 29.9 (C-13), 32.3 (C-16), 33.9 (C-2), 36.7 (C-7), 40.8 (C-17), 41.7 (C-8), 43.1 (C-4), 43.8 (C-5), 45.4 (C-12), 45.9 (C-10), 52.2 (C-9), 67.3 (C-1), 69.9 (C-14), 72.3 (C-11); HR-ESIMS m/z $463.0847[\mathrm{M}-\mathrm{H}]^{-}$(calcd. for $\mathrm{C}_{20} \mathrm{H}_{33}{ }^{79} \mathrm{Br}_{2} \mathrm{O}_{2}, 463.0853$ ).

Compound 6: Gummy solid; ${ }^{1} \mathrm{H}$ NMR $\left(600 \mathrm{MHz}, \mathrm{CDCl}_{3}\right) \delta 0.94(3 \mathrm{H}, \mathrm{d}, J=6.9 \mathrm{~Hz}$, $\left.\mathrm{H}_{3}-20\right), 1.01$ (1H, m, H-6b), $1.06\left(3 \mathrm{H}, \mathrm{d}, J=6.9 \mathrm{~Hz}, \mathrm{H}_{3}-19\right), 1.16\left(3 \mathrm{H}, \mathrm{s}, \mathrm{H}_{3}-15\right), 1.22(1 \mathrm{H}, \mathrm{m}$, $\mathrm{H}-4), 1.25$ (1H, m, H-7b), 1.30 (3H, s, H3-16), $1.31(1 \mathrm{H}, \mathrm{d}, J=11.2 \mathrm{~Hz}, \mathrm{H}-9), 1.47$ (1H, td, $J=13.3,6.2 \mathrm{~Hz}, \mathrm{H}-2 \mathrm{~b}), 1.54$ (1H, ddd, $J=14.0,4.5,3.0 \mathrm{~Hz}, \mathrm{H}-12 \mathrm{~b}), 1.58$ (1H, m, H-3b), 1.63 $(1 \mathrm{H}, \mathrm{ddd}, J=14.0,13.0,4.6 \mathrm{~Hz}, \mathrm{H}-12 \mathrm{a}), 1.71(1 \mathrm{H}, \mathrm{m}, \mathrm{H}-2 \mathrm{a}), 1.81$ (1H, ddd, $J=14.3,13.3$, 7.3 Hz, H-3a), 1.86 (1H, m, H-7a), 1.88 (1H, m, H-6a), 2.06 (1H, dddd, $J=13.0,4.6,4.2,3.0$ Hz, H-13ß), 2.10 (1H, qd, J = 6.9, $2.0 \mathrm{~Hz}, \mathrm{H}-18), 2.18(1 \mathrm{H}, \mathrm{d}, J=11.2 \mathrm{~Hz}, \mathrm{H}-10), 2.47(1 \mathrm{H}$, $\mathrm{qd}, J=13.0,4.5 \mathrm{~Hz}, \mathrm{H}-13 \alpha), 3.58(1 \mathrm{H}, \mathrm{d}, J=8.3 \mathrm{~Hz}, \mathrm{H}-17 \mathrm{~b}), 3.87$ (1H, d, $J=8.3 \mathrm{~Hz}, \mathrm{H}-17 \mathrm{a})$, $3.96(1 \mathrm{H}, \mathrm{dd}, J=13.0,4.2 \mathrm{~Hz}, \mathrm{H}-14), 4.74(1 \mathrm{H}, \mathrm{brd}, J=4.8 \mathrm{~Hz}, \mathrm{H}-1) ;{ }^{13} \mathrm{C}$ NMR $(150 \mathrm{MHz}$, $\left.\mathrm{CDCl}_{3}\right) \delta 16.1$ (C-15), 18.8 (C-3), 20.2 (C-19), 22.4 (C-6), 26.9 (C-20), 27.3 (C-18), 30.7 (C-13), 32.0 (C-2), 33.9 (C-16), 36.7 (C-7), 40.3 (C-8), 42.0 (C-10), 44.1 (C-12), 48.3 (C-9), 48.5 (C-5), 50.7 (C-4), 68.3 (C-14), 73.0 (C-11), 76.2 (C-17), 81.9 (C-1); HR-ESIMS m/z 385.1735 [M+H] ${ }^{+}$ (calcd. for $\mathrm{C}_{20} \mathrm{H}_{34}{ }^{79} \mathrm{BrO}_{2}, 385.1737$ ).

\subsubsection{Synthesis of Analogs 7 and 8}

To a stirred solution of bromosphaerol (1) $(220 \mathrm{mg}, 0.48 \mathrm{mmol})$ in anhydrous 1,4dioxane $(1.4 \mathrm{~mL})$, a solution of $70 \% \mathrm{HClO}_{4}(0.28 \mathrm{~mL}, 1.8 \mathrm{mmol})$ and water $(1.4 \mathrm{~mL})$ was added dropwise, followed by the addition of a suspension of $N$-bromoacetamide $(0.13 \mathrm{~g}$, $0.95 \mathrm{mmol})$ in water $(0.5 \mathrm{~mL})$. The reaction mixture was stirred for $2 \mathrm{~h}$ at $25^{\circ} \mathrm{C}$ (the completion of the reaction was monitored by TLC), saturated aqueous $\mathrm{Na}_{2} \mathrm{~S}_{2} \mathrm{O}_{3}$ solution (1 mL) was added, and the resulting mixture was stirred for $30 \mathrm{~min}$. Subsequently, the mixture was poured into ice water and extracted with $\mathrm{CH}_{2} \mathrm{Cl}_{2}(3 \times 15 \mathrm{~mL})$. The combined organic layers were washed with $\mathrm{NaHCO}_{3}$, dried over anhydrous $\mathrm{Na}_{2} \mathrm{SO}_{4}$, and concentrated under reduced pressure. The residue was purified by flash column chromatography (elution system: petroleum ether $40-65{ }^{\circ} \mathrm{C} /$ acetone, 90:10) to afford compound 7 (141 $\mathrm{mg}, 40 \%$ yield) and 8 (152 $\mathrm{mg}, 38 \%$ ).

Compound 7: Gummy solid; ${ }^{1} \mathrm{H}$ NMR $\left(600 \mathrm{MHz}, \mathrm{CDCl}_{3}\right) \delta 0.84(3 \mathrm{H}, \mathrm{d}, J=6.7 \mathrm{~Hz}$, $\left.\mathrm{H}_{3}-19\right), 0.99$ (3H, d, $\left.J=6.7 \mathrm{~Hz}, \mathrm{H}_{3}-20\right), 1.14\left(3 \mathrm{H}, \mathrm{s}, \mathrm{H}_{3}-15\right), 1.34\left(3 \mathrm{H}, \mathrm{s}, \mathrm{H}_{3}-16\right), 1.39(1 \mathrm{H}$, m, H-7b), 1.44 (1H, m, H-6b), 1.50 (1H, m, H-12b), 1.64 (2H, m, H-6a, H-12a), 1.86 (1H, m, 
H-18), 1.92 (1H, m, H-7a), 2.00 (1H, m, H-4), 2.02 (1H, m, H-13ß), 2.15 (1H, s, H-9), 2.24 (1H, m, H-3b), $2.38(1 \mathrm{H}, \mathrm{dd}, J=13.1,5.9 \mathrm{~Hz}, \mathrm{H}-3 \mathrm{a}), 2.45(1 \mathrm{H}, \mathrm{qd}, J=12.8,5.7 \mathrm{~Hz}, \mathrm{H}-13 \alpha), 3.55$ $(1 \mathrm{H}, \mathrm{d}, J=11.2 \mathrm{~Hz}, \mathrm{H}-17 \mathrm{~b}), 3.91(1 \mathrm{H}, \mathrm{d}, J=11.2 \mathrm{~Hz}, \mathrm{H}-17 \mathrm{a}), 4.02(1 \mathrm{H}, \mathrm{dd}, J=12.8,3.7 \mathrm{~Hz}$, $\mathrm{H}-14), 6.97(1 \mathrm{H}, \mathrm{s}, \mathrm{H}-1) ;{ }^{13} \mathrm{C}$ NMR $\left(75 \mathrm{MHz}, \mathrm{CDCl}_{3}\right) \delta 15.2$ (C-15), 18.7, 24.2, 26.1, 26.8, 29.7, 29.7, 33.5, 37.1, 37.2, 41.5, 44.6, 45.1, 46.9, 52.8 (C-9), 66.8 (C-14), 71.7 (C-11), 130.0 (C-1), 161.1 (C-10), 200.0 (C-2); HR-ESIMS $m / z$ 461.0688 [M+H] ${ }^{+}$(calcd. for $\mathrm{C}_{20} \mathrm{H}_{31}{ }^{79} \mathrm{Br}_{2} \mathrm{O}_{2}, 461.0685$ ).

Compound 8: Gummy solid; ${ }^{1} \mathrm{H}$ NMR $\left(600 \mathrm{MHz}, \mathrm{CDCl}_{3}\right) \delta 0.97(3 \mathrm{H}, \mathrm{d}, J=6.0 \mathrm{~Hz}$, $\left.\mathrm{H}_{3}-19\right), 1.19\left(3 \mathrm{H}, \mathrm{s}, \mathrm{H}_{3}-16\right), 1.19\left(3 \mathrm{H}, \mathrm{d}, J=6.0 \mathrm{~Hz}, \mathrm{H}_{3}-20\right), 1.21\left(3 \mathrm{H}, \mathrm{s}, \mathrm{H}_{3}-15\right), 1.23(1 \mathrm{H}, \mathrm{m}$, H-7b), $1.32(1 \mathrm{H}, \mathrm{d}, J=12.7 \mathrm{~Hz}, \mathrm{H}-9), 1.64(1 \mathrm{H}, \mathrm{ddd}, J=13.6,4.1,2.7 \mathrm{~Hz}, \mathrm{H}-7 \mathrm{a}), 1.72(1 \mathrm{H}, \mathrm{dd}$, $J=13.2,7.7 \mathrm{~Hz}, \mathrm{H}-12 \mathrm{~b}), 1.78$ (1H, m, H-6b), $1.83(1 \mathrm{H}, \mathrm{m}, \mathrm{H}-4), 1.91(1 \mathrm{H}, \mathrm{m}, \mathrm{H}-18), 2.03-2.07$ (3H, m, H-3b, H-6a, H-12a), 2.22 (1H, m, H-13b), 2.32 (1H, ddt, J = 16.3, 11.0, 8.3 Hz, H-13a), $2.49(1 \mathrm{H}, \mathrm{ddd}, J=16.8,3.2,1.4 \mathrm{~Hz}, \mathrm{H}-3 \mathrm{a}), 2.58(1 \mathrm{H}, \mathrm{dd}, J=12.7,11.8 \mathrm{~Hz}, \mathrm{H}-10), 3.34(1 \mathrm{H}, \mathrm{dd}$, $J=11.8,3.2 \mathrm{~Hz}, \mathrm{H}-1), 3.47(1 \mathrm{H}, \mathrm{dd}, J=10.5,2.0 \mathrm{~Hz}, \mathrm{H}-17 \mathrm{~b}), 3.78(1 \mathrm{H}, \mathrm{d}, J=10.5 \mathrm{~Hz}, \mathrm{H}-17 \mathrm{a})$, $3.87(1 \mathrm{H}, \mathrm{t}, J=8.3 \mathrm{~Hz}, \mathrm{H}-14), 4.58(1 \mathrm{H}, \mathrm{q}, J=3.2 \mathrm{~Hz}, \mathrm{H}-2) ;{ }^{13} \mathrm{C}$ NMR $\left(75 \mathrm{MHz}, \mathrm{CDCl}_{3}\right) \delta 15.7$ (C-15), 23.9 (C-20), 26.1 (C-19), 26.7 (C-18), 28.9 (C-16), 29.6 (C-6), 30.2 (C-3), 31.2 (C-13), 32.8 (C-12), 38.4 (C-17), 39.2 (C-7), 42.7 (C-8), 42.6 (C-5), 43.5 (C-10), 46.2 (C-4), 51.7 (C-2), 52.9 (C-9), 59.4 (C-14), 72.9 (C-1), 80.9 (C-11); HR-ESIMS m/z 546.9822 [M+Na] ${ }^{+}$(calcd. for $\left.\mathrm{C}_{20} \mathrm{H}_{31}{ }^{79} \mathrm{Br}_{3} \mathrm{ONa}, 546.9817\right)$.

\subsubsection{Synthesis of Analogs 9 and $\mathbf{1 0}$}

To a solution of bromosphaerol (1) $(100 \mathrm{mg}, 0.216 \mathrm{mmol})$, a catalytic amount of trimethylsilyl triflate $(2 \mu \mathrm{L}, 0.011 \mathrm{mmol})$ was added in acetic anhydride $(0.43 \mathrm{~mL}$, $0.432 \mathrm{mmol})$ at $-10{ }^{\circ} \mathrm{C}$. The reaction was stirred for $1 \mathrm{~h}$, quenched with water $(1 \mathrm{~mL})$, and extracted with $\mathrm{CH}_{2} \mathrm{Cl}_{2}(3 \times 15 \mathrm{~mL})$. The combined organic layers were washed with saturated aqueous $\mathrm{NaHCO}_{3}$ solution $(5 \mathrm{~mL})$, dried over anhydrous $\mathrm{Na}_{2} \mathrm{SO}_{4}$, and evaporated under reduced pressure. Compounds $9(65 \mathrm{mg}, 70 \%$ yield $)$ and $10(9 \mathrm{mg}, 10 \%$ yield) were isolated by flash column chromatography (elution system: petroleum ether $40-65{ }^{\circ} \mathrm{C} /$ acetone 90:10). Comparison of the spectroscopic and physical characteristics of 9 and $\mathbf{1 0}$ with those reported in the literature [38] allowed for their identification.

\subsubsection{Synthesis of Analog 11}

To a solution of compound $7(28 \mathrm{mg}, 0.061 \mathrm{mmol})$ and triethylphosphonoacetate $(0.14 \mathrm{~g}, 0.61 \mathrm{mmol})$ in a mixture of abs. EtOH and anhydrous THF (1:1) $(0.40 \mathrm{~mL})$, a solution of sodium ethanolate, prepared from $\mathrm{Na}(14 \mathrm{mg}, 0.61 \mathrm{mmol})$ in abs. $\mathrm{EtOH}(0.29 \mathrm{~mL})$ was added dropwise. The reaction mixture was stirred for $12 \mathrm{~h}$ at $25^{\circ} \mathrm{C}$, quenched with water $(5.0 \mathrm{~mL})$, and diluted with diethyl ether $(10 \mathrm{~mL})$. Subsequently, the aqueous layer was extracted with diethyl ether $(3 \times 15 \mathrm{~mL})$. The combined organic layers were washed successively with $5 \%$ aqueous $\mathrm{HCl}$ solution, $5 \%$ aqueous $\mathrm{NaHCO}_{3}$ solution, and water, dried over anhydrous $\mathrm{Na}_{2} \mathrm{SO}_{4}$, and evaporated in vacuo. Compound 11 ( $29.5 \mathrm{mg}, 90 \%$ yield) was isolated as a mixture of $E, Z$ geometric isomers after purification by flash column chromatography (elution system: hexane/acetone 90:10).

Compound 11: Gummy solid; ${ }^{1} \mathrm{H}$ NMR $\left(600 \mathrm{MHz}, \mathrm{CDCl}_{3}\right) \delta 0.85$ and $0.90(3 \mathrm{H}, 2 \mathrm{~d}$, $J=6.6 \mathrm{~Hz}), 1.00$ and $1.03(3 \mathrm{H}, 2 \mathrm{~d}, J=6.9 \mathrm{~Hz}), 1.12$ and $1.15(3 \mathrm{H}, 2 \mathrm{~s}), 1.25-1.44(7 \mathrm{H}, \mathrm{m})$, 1.63-2.10 (9H, m), 2.22-2.55 (2H, m), 3.47-3.71 (2H, m), $3.90(1 \mathrm{H}, \mathrm{d}, J=11.2 \mathrm{~Hz}), 4.02-4.19$ $(3 \mathrm{H}, \mathrm{m}), 5.54$ and $5.67(1 \mathrm{H}, 2 \mathrm{~s}), 7.00(0.4 \mathrm{H}, \mathrm{s}), 8.19(0.6 \mathrm{H}, \mathrm{s}) ;{ }^{13} \mathrm{C} \mathrm{NMR}\left(75 \mathrm{MHz}, \mathrm{CDCl}_{3}\right) \delta$ 14.6, 15.0, 15.5, 15.4, 18.9, 18.8, 21.4, 24.7, 24.6, 26.5, 26.3, 27.3, 27.2, 28.4, 29.7, 29.8, 29.9, 30.1, $30.5,37.8,38.1,38.2,41.7,42.9,44.4,44.5,44.9,45.1,46.2,46.7,52.6,52.8,59.6,59.7,67.4,67.9$, 72.2, 72.3, 112.7, 115.2, 126.5, 130.8, 147.1, 147.5, 153.0, 154.3, 166.8, 167.5; HR-ESIMS m/z $553.0921[\mathrm{M}+\mathrm{Na}]^{+}$(calcd. for $\mathrm{C}_{24} \mathrm{H}_{36}{ }^{79} \mathrm{Br}_{2} \mathrm{O}_{3} \mathrm{Na}$ 553.0923).

\subsubsection{Synthesis of Analogs 12-16}

To a solution of compound $7(0.05 \mathrm{mmol})$ in anhydrous pyridine $(0.45 \mathrm{~mL})$, the appropriate alkoxyalkylamine salt $(0.1 \mathrm{mmol})$ was added, and the reaction mixture was stirred for $12 \mathrm{~h}$ at $25^{\circ} \mathrm{C}$. Subsequently, the solvent was evaporated under reduced pressure, and to the 
residue, $\mathrm{CH}_{2} \mathrm{Cl}_{2}(10 \mathrm{~mL})$ and water $(5 \mathrm{~mL})$ were added. The aqueous layer was extracted with $\mathrm{CH}_{2} \mathrm{Cl}_{2}(2 \times 10 \mathrm{~mL})$, and the combined organic layers were dried over anhydrous $\mathrm{Na}_{2} \mathrm{SO}_{4}$ and concentrated under reduced pressure. The final products were isolated after purification by flash column chromatography.

Following the general procedure described above, using compound 7 (21 $\mathrm{mg}$, $0.045 \mathrm{mmol})$, pyridine $(0.4 \mathrm{~mL})$, and hydroxylamine hydrochloride $(6.3 \mathrm{mg}, 0.09 \mathrm{mmol})$, compound 12 was obtained (20.6 mg, 95\% yield, mixture of $E, Z$ geometric isomers) after purification by flash column chromatography (elution system: petroleum ether 40-65 ${ }^{\circ} \mathrm{C}$ /acetone, 80:20).

Compound 12: Gummy solid; ${ }^{1} \mathrm{H}$ NMR (600 MHz, $\left.\mathrm{CDCl}_{3}\right) \delta 0.87$ and $0.89(3 \mathrm{H}, 2 \mathrm{~d}$, $J=6.7 \mathrm{~Hz}), 1.04-1.02(3 \mathrm{H}, \mathrm{m}), 1.13$ and $1.14(3 \mathrm{H}, 2 \mathrm{~s}), 1.33-1.45(2 \mathrm{H}, \mathrm{m}), 1.43$ and $1.48(3 \mathrm{H}$, $2 \mathrm{~d}, J=6.9 \mathrm{~Hz}), 1.61-1.65(2 \mathrm{H}, \mathrm{m}), 1.81-2.27(8 \mathrm{H}, \mathrm{m}), 2.40-2.55(1 \mathrm{H}, \mathrm{m}), 3.49-3.56(1 \mathrm{H}, \mathrm{m})$, 3.87-3.94 (1H, m), $4.03(1 \mathrm{H}, \mathrm{dd}, J=12.7,3.7 \mathrm{~Hz}), 6.98(0.67 \mathrm{H}, \mathrm{s}), 7.31-7.33(0.67 \mathrm{H}, \mathrm{bs}), 7.57$ $(0.33 \mathrm{H}, \mathrm{s}), 7.70(0.33 \mathrm{H}, \mathrm{t}, J=7.7 \mathrm{~Hz}) ;{ }^{13} \mathrm{C} \mathrm{NMR}\left(75 \mathrm{MHz}, \mathrm{CDCl}_{3}\right) \delta 15.4,17.4,18.8,18.9,24.0$, 24.5, 24.6, 26.3, 26.4, 27.2, 27.3, 29.8, 29.9, 30.0, 30.1, 37.6, 37.7, 37.8, 38.1, 40.6, 42.6, 44.3, 44.9, 46.3, 47.2, 52.5, 52.7, 67.5, 67.7, 72.1, 118.1, 124.4, 136.4, 146.5, 149.6, 149.7; HR-ESIMS m/z 476.0796 [M+H] ${ }^{+}$(calcd. for $\mathrm{C}_{20} \mathrm{H}_{32}{ }^{79} \mathrm{Br}_{2} \mathrm{NO}_{2}, 476.0794$ ), $m / z 498.0617$ [M+Na] ${ }^{+}$(calcd. for $\left.\mathrm{C}_{20} \mathrm{H}_{31}{ }^{79} \mathrm{Br}_{2} \mathrm{NO}_{2} \mathrm{Na}, 498.0614\right)$.

Following the general procedure described above, using compound 7 (20 mg, 0.043 $\mathrm{mmol})$, pyridine $(0.4 \mathrm{~mL})$, and methoxyamine hydrochloride $(7.2 \mathrm{mg}, 0.086 \mathrm{mmol})$, compound 13 was obtained ( $21 \mathrm{mg}, 98 \%$ yield, mixture of $E, Z$ geometric isomers) after purification by flash column chromatography (elution system: petroleum ether $40-65^{\circ} \mathrm{C} /$ acetone, 90:10).

Compound 13: Gummy solid; ${ }^{1} \mathrm{H} \mathrm{NMR}\left(600 \mathrm{MHz}, \mathrm{CDCl}_{3}\right) \delta 0.86$ and $0.88(3 \mathrm{H}, 2 \mathrm{~d}$, $J=6.7 \mathrm{~Hz}), 1.02-1.04(3 \mathrm{H}, \mathrm{m}), 1.14$ and $1.15(3 \mathrm{H}, 2 \mathrm{~s}), 1.34-1.43(2 \mathrm{H}, \mathrm{m}), 1.39$ and $1.42(3 \mathrm{H}$, $2 \mathrm{~s}), 1.58-1.68(2 \mathrm{H}, \mathrm{m}), 1.78-2.31(8 \mathrm{H}, \mathrm{m}), 2.45-2.51(1 \mathrm{H}, \mathrm{m}) 3.49-3.54(1 \mathrm{H}, \mathrm{m}), 3.86$ and $3.92(3 \mathrm{H}, 2 \mathrm{~s}), 3.85-3.90(1 \mathrm{H}, \mathrm{m}), 4.03(1 \mathrm{H}, \mathrm{dd}, J=12.7,3.9 \mathrm{~Hz}), 6.96(0.29 \mathrm{H}, \mathrm{s}), 7.46(0.71 \mathrm{H}$, s); ${ }^{13} \mathrm{C} \mathrm{NMR}\left(75 \mathrm{MHz}, \mathrm{CDCl}_{3}\right) \delta 15.4,15.5,18.0,18.9,24.1,24.6,24.7,26.3,26.4,27.1,27.2$, 29.9, 29.96, 30.0, 37.6, 37.7, 37.76, 37.8, 38.1, 40.6, 42.6, 44.3, 44.4, 44.9, 46.2, 47.2, 52.4, 52.7, $61.8,61.9,67.4,67.7,72.17,72.20,118.6,124.4,146.5,149.7,156.2,156.3$; HR-ESIMS $m / z$ 490.0952 [M+H] ${ }^{+}$(calcd. for $\mathrm{C}_{21} \mathrm{H}_{34}{ }^{79} \mathrm{Br}_{2} \mathrm{NO}_{2}, 490.0951$ ), $m / z 512.0772[\mathrm{M}+\mathrm{Na}]^{+}$(calcd. for $\left.\mathrm{C}_{21} \mathrm{H}_{33}{ }^{79} \mathrm{Br}_{2} \mathrm{NO}_{2} \mathrm{Na}, 512.0770\right)$.

Following the general procedure described above, using compound 7 ( $25.5 \mathrm{mg}, 0.055$ $\mathrm{mmol})$, pyridine $(0.45 \mathrm{~mL})$, and $\mathrm{O}$-(carboxymethyl)hydroxylamine hemihydrochloride (24.1 mg, $0.22 \mathrm{mmol})$, compound 14 was obtained $(28.3 \mathrm{mg}, 96 \%$ yield, mixture of $E, Z$ geometric isomers) after purification by flash column chromatography (elution system: $\left.\mathrm{CH}_{2} \mathrm{Cl}_{2} / \mathrm{MeOH}, 90: 10\right)$.

Compound 14: Gummy solid; ${ }^{1} \mathrm{H}$ NMR (600 MHz, $\left.\mathrm{CDCl}_{3} / \mathrm{CD}_{3} \mathrm{OD}\right) \delta 0.81$ and 0.84 $(3 \mathrm{H}, 2 \mathrm{~d}, J=6.8 \mathrm{~Hz}), 0.97$ and $0.99(3 \mathrm{H}, 2 \mathrm{~d}, J=6.9 \mathrm{~Hz}), 1.07$ and $1.09(3 \mathrm{H}, 2 \mathrm{~s}), 1.29$ and $1.35(3 \mathrm{H}, 2 \mathrm{~s}), 1.32-1.40(2 \mathrm{H}, \mathrm{m}), 1.51-1.66(2 \mathrm{H}, \mathrm{m}), 1.76-2.16(8 \mathrm{H}, \mathrm{m}), 2.41-2.49(1 \mathrm{H}, \mathrm{m})$, 3.45-3.50 (1H, m), 3.85-3.89 (1H, m), 3.98-4.02 (1H, m), 4.46-4.47 (2H, m), $6.91(0.42 \mathrm{H}, \mathrm{s})$, $7.42(0.58 \mathrm{H}, \mathrm{s}) ;{ }^{13} \mathrm{C} \mathrm{NMR}\left(150 \mathrm{MHz}, \mathrm{CDCl}_{3} / \mathrm{CD}_{3} \mathrm{OD}\right) \delta 15.4,15.5,18.4,18.8,18.9,21.9,24.0$, $24.5,24.6,26.3,26.4,27.2,27.3,29.88,29.90,29.94,30.00,37.5,37.6,37.7,37.9,40.5,42.5,44.4$, $44.5,44.7,44.8,46.3,47.2,52.6,52.8,67.2,67.4,70.2,70.3,72.1,72.2,118.4,123.6,148.5,151.5$, 156.1, 158.1, 173.9, 174.4; HR-ESIMS $m / z$ 556.0674 [M+Na] $]^{+}$(calcd. for $\mathrm{C}_{22} \mathrm{H}_{33}{ }^{79} \mathrm{Br}_{2} \mathrm{NO}_{4} \mathrm{Na}$, 556.0669).

Following the general procedure described above, using compound 7 (30 $\mathrm{mg}$, $0.065 \mathrm{mmol})$, pyridine $(0.5 \mathrm{~mL})$, and methyl 2 -(aminooxy)acetate hydrochloride $(27.3 \mathrm{mg}$, $0.26 \mathrm{mmol}$ ) [39], compound 15 was obtained $(20.5 \mathrm{mg}, 56 \%$ yield, mixture of $E, Z$ geometric isomers) after purification by flash column chromatography (elution system: petroleum ether $40-65{ }^{\circ} \mathrm{C} /$ acetone, 90:10).

Compound 15: Gummy solid; ${ }^{1} \mathrm{H}$ NMR (300 MHz, $\left.\mathrm{CDCl}_{3}\right) \delta 0.85$ and $0.89(3 \mathrm{H}, 2 \mathrm{~d}$, $J=6.7 \mathrm{~Hz}), 1.02$ and $1.04(3 \mathrm{H}, 2 \mathrm{~d}, J=7.2 \mathrm{~Hz}), 1.14$ and $1.16(3 \mathrm{H}, 2 \mathrm{~s}), 1.37$ and $1.42(3 \mathrm{H}, 2 \mathrm{~s})$, 1.37-1.45 (2H, m), 1.59-1.67 (2H, m), 1.78-2.26 (8H, m), 2.40-2.55 (1H, m), 3.48-3.56 (1H, 
$\mathrm{m}), 3.77$ and $3.75(3 \mathrm{H}, 2 \mathrm{~s}), 3.86-3.93(1 \mathrm{H}, \mathrm{m}), 4.03(1 \mathrm{H}, \mathrm{dd}, J=12.4,3.7 \mathrm{~Hz}), 4.57-4.66(2 \mathrm{H}$, m), $6.93(0.38 \mathrm{H}, \mathrm{s}), 7.55(0.62 \mathrm{H}, \mathrm{s}) ;{ }^{13} \mathrm{C} \mathrm{NMR}\left(75 \mathrm{MHz}, \mathrm{CDCl}_{3}\right) \delta 15.4,15.5,18.3,18.8,18.9$, 24.0, 24.5, 24.7, 26.3, 26.4, 27.1, 27.3, 29.9, 29.93, 29.97, 30.0, 37.64, 37.67, 37.7, 38.0, 40.5, $42.4,44.3,44.4,44.9,46.3,47.1,52.0,52.1,52.5,52.7,67.4,67.5,70.4,70.6,72.1,72.2,118.7$, 124.0, 147.3, 150.0, 155.0, 157.8, 170.8, 171.0; HR-APCIMS m/z 548.1008 [M+H] ${ }^{+}$(calcd. for $\left.\mathrm{C}_{23} \mathrm{H}_{36}{ }^{79} \mathrm{Br}_{2} \mathrm{NO}_{4}, 548.1006\right)$.

Following the general procedure described above, using compound 7 (21 mg, $0.045 \mathrm{mmol})$, pyridine $(0.4 \mathrm{~mL})$, and $\mathrm{O}-(\mathrm{N}, \mathrm{N}$-dimethylaminoethyl)hydroxylamine hydrochloride [40] (32 mg, $0.18 \mathrm{mmol})$, compound 16 was obtained (17.5 mg, 81\% yield, mixture of $E, Z$ geometric isomers) after purification by flash column chromatography (elution system: $\mathrm{CH}_{2} \mathrm{Cl}_{2} / \mathrm{MeOH}, 95: 5$ ).

Compound 16: Gummy solid; ${ }^{1} \mathrm{H}$ NMR (300 MHz, $\left.\mathrm{CDCl}_{3} / \mathrm{CD}_{3} \mathrm{OD}\right) \delta 0.78(3 \mathrm{H}, \mathrm{d}$, $J=7.0 \mathrm{~Hz}), 0.94(3 \mathrm{H}, \mathrm{d}, J=6.9 \mathrm{~Hz}), 1.05(3 \mathrm{H}, \mathrm{s}), 1.27(3 \mathrm{H}, \mathrm{s}), 1.17-2.11(11 \mathrm{H}, \mathrm{m}), 2.33$ and $2.41(6 \mathrm{H}, 2 \mathrm{~s}), 2.33-2.47(2 \mathrm{H}, \mathrm{m}), 2.71-2.83(2 \mathrm{H}, \mathrm{m}), 3.41-3.47(1 \mathrm{H}, \mathrm{m}), 3.81-3.87(1 \mathrm{H}, \mathrm{m})$, $3.97(1 \mathrm{H}, \mathrm{dd}, J=12.7,3.7 \mathrm{~Hz}), 4.12-4.25(2 \mathrm{H}, \mathrm{m}), 6.89(0.34 \mathrm{H}, \mathrm{s}), 7.41(0.66 \mathrm{H}, \mathrm{s}) ;{ }^{13} \mathrm{C} \mathrm{NMR}$ (75 MHz, $\left.\mathrm{CDCl}_{3} / \mathrm{CD}_{3} \mathrm{OD}\right) \delta$ 15.0, 15.1, 18.6, 23.8, 24.3, 24.4, 26.1, 26.2, 27.1, 29.0, 29.3, 29.6, 29.8, 29.9, 37.3, 37.4, 37.6, 37.9, 40.6, 42.5, 44.3, 44.4, 44.5, 44.8, 45.2, 46.1, 47.0, 52.5, 52.7, $57.3,57.5,67.8,67.9,69.9,70.9,118.4,123.7,151.0,154.8$; HR-APCIMS m/z 547.1533 [M+H] ${ }^{+}$ (calcd. for $\mathrm{C}_{24} \mathrm{H}_{41}{ }^{79} \mathrm{Br}_{2} \mathrm{~N}_{2} \mathrm{O}_{2}, 547.1529$ ).

\subsection{Evaluation of Settlement Inhibitory Activity}

Cypris larvae were obtained from laboratory cultures of the crustacean cirriped A. amphitrite brood stock. Twenty to thirty adult barnacles were reared in $800 \mathrm{~mL}$ aerated beakers containing filtered natural seawater (FNSW) at $20 \pm 1{ }^{\circ} \mathrm{C}$, with a $16 \mathrm{~h}: 8 \mathrm{~h}$ light:dark (L:D) cycle. They were fed every two days with nauplii of Artemia salina (100 mL, 20-35 larvae/mL) and Tetraselmis suecica (100 mL, $2 \times 10^{5}$ cells $\left./ \mathrm{mL}\right)$. Twenty beakers containing adults reared under the above-mentioned conditions produced nauplii throughout the year. Nauplii were collected with a $5 \mathrm{~mL}$ pipette by positioning the beaker near a light source and reared in $500 \mathrm{~mL}$ beakers containing $0.22 \mu \mathrm{m}$ FNSW gently aerated at $28 \pm 1{ }^{\circ} \mathrm{C}$ with a 16 h:8 h L:D cycle. Nauplii were fed every $48 \mathrm{~h}$ with $T$. suecica $\left(5 \times 10^{5}\right.$ cells $\left./ \mathrm{mL}\right)$ until, after 5-6 days, they reached the cyprid stage.

Newly metamorphosed cyprids were filtered and maintained in $0.22 \mu \mathrm{m}$ FNSW at $6{ }^{\circ} \mathrm{C}$ for 4 days before being used in settlement assays [41]. Settlement tests were performed by adding 15-20 cyprids (for each replicate) to 24-well polystyrene plates containing $2 \mathrm{~mL}$ of bromosphaerol derivatives at different concentrations $(0,0.5,5$, and $50 \mathrm{mg} / \mathrm{L})$. Four replicates were prepared for each concentration of each derivative, and the reported results are the mean values of the four replicates. The 24 -well plates were stored for $72 \mathrm{~h}$ at $28{ }^{\circ} \mathrm{C}$ with a 16:8 L:D cycle. After 24,48 , and $72 \mathrm{~h}$, the number of settled, non-settled, and dead larvae was measured under a stereomicroscope. $\mathrm{EC}_{50}$ values (concentration of bromosphaerol derivatives causing 50\% settlement inhibition to exposed organisms) were calculated with the results obtained after $72 \mathrm{~h}$. Additionally, at the same time, $\mathrm{LC}_{50 \text { (cypris) }}$ values were calculated as the concentration of bromosphaerol derivatives causing $50 \%$ mortality to the exposed organisms.

\subsection{Evaluation of Toxicity}

Acute environmental toxicity of bromosphaerol derivatives was tested by using stage II nauplii of $A$. amphitrite. Nauplii were obtained from adult brood stock as described above, collected, and immediately filtered in $0.22 \mu \mathrm{m}$ FNSW. The toxicity assay was set within 2-4 h from nauplii collection. The test was performed by adding 15 to 25 stage II nauplii to 24-well polystyrene plates containing $2 \mathrm{~mL}$ of bromosphaerol derivatives at different concentrations $(0,0.5,5$, and $50 \mathrm{mg} / \mathrm{L})$. Four replicates were prepared for each concentration of each derivative, and the reported results are the mean values of the four replicates. The plates were stored for $48 \mathrm{~h}$ at $20^{\circ} \mathrm{C}$ with a 16:8 L:D cycle. After 24 and $48 \mathrm{~h}$, the number of dead larvae was observed under a stereomicroscope. LC $_{50(\text { nauplii) }}$ values 
were calculated as the concentration of bromosphaerol derivatives causing $50 \%$ mortality to the exposed organisms after $48 \mathrm{~h}$ of contact.

\subsection{Statistical Analysis}

Settlement inhibition $\left(\mathrm{EC}_{50}\right)$ at $72 \mathrm{~h}$ and mortality $\left(\mathrm{LC}_{50}\right)$ values at $48 \mathrm{~h}$ (for nauplii) and $72 \mathrm{~h}$ (for cyprids) were calculated using trimmed Spearman-Karber analysis [42]. The therapeutic ratio $(\mathrm{TN})$ was defined as $\mathrm{LC}_{50} / \mathrm{EC}_{50}$. This index was calculated using mortality values measured for larvae at naupliar stage $\left(\mathrm{TR}_{\mathrm{N}}\right)$ and for larvae at cypris stage $\left(\mathrm{TR}_{\mathrm{C}}\right)$.

\section{Conclusions}

Following different synthetic routes, we successfully synthesized 15 structural analogs (2-16) of bromosphaerol (1) decorated with different functional groups. The anti-settlement activity $\left(\mathrm{EC}_{50}\right)$ and the degree of toxicity $\left(\mathrm{LC}_{50}\right)$ of the bromosphaerol derivatives were evaluated using cyprids and nauplii of $A$. amphitrite as a model organism. Derivatives 2, 4, and 6-16 showed diverse levels of antifouling activity, with four of them $(9,13,15$, and 16) displaying a bioactivity comparable to the one of the naturally occurring molecule. Among them, compounds $\mathbf{9}$ and $\mathbf{1 3}$ can be considered as well-performing antifoulants, exerting their activity through a non-toxic mechanism. The chemical diversity of these derivatives provides new insights on structure-activity relationship studies regarding settlement inhibition, helping to understand the antifouling mechanism of bromosphaerol (1), while potentially serving as bioinspired alternatives in antifouling coatings and paints.

Supplementary Materials: The following are available online at https:/ /www.mdpi.com/article/10 .3390/md20010007/s1, Figures S1-S46: 1D and 2D NMR spectra of compounds 1-16.

Author Contributions: Conceptualization, E.I., T.C. and V.R.; methodology, K.C.P., E.I., T.C. and V.R.; formal analysis, K.C.P., E.I., T.C. and V.R.; investigation, K.C.P., S.K., E.I., S.M., M.F. and V.P.; resources, E.I., T.C. and V.R.; writing — original draft preparation, K.C.P., S.K. and V.P.; writing-review and editing, E.I., T.C. and V.R.; visualization, K.C.P., S.K. and E.I.; supervision, E.I., T.C. and V.R.; project administration, E.I. and V.R.; funding acquisition, E.I., T.C. and V.R. All authors have read and agreed to the published version of the manuscript.

Funding: This research was partially supported by the Cooperation 2011 Action of the Operational Programme "Competitiveness and Entrepreneurship" with co-funding by the European Social Fund (ESF) and National Resources, Greece (project GSRT-EPANII-11 IYN-5-1274 "MariPaints"). Part of the current work was financially supported by the project "OPENSCREEN-GR: An Open-Access Research Infrastructure of Chemical Biology and Target-Based Screening Technologies for Human and Animal Health Agriculture and the Environment" (2018-2020) (MIS 5002691), which is implemented under the Action "Reinforcement of the Research and Innovation Infrastructure", funded by the Operational Programme "Competitiveness, Entrepreneurship and Innovation" (NSRF 2014-2020) and co-financed by Greece and the European Union (European Regional Development Fund).

Data Availability Statement: The data presented in this study are available in Supplementary Material.

Acknowledgments: Access to the infrastructure obtained by the research project "Center for the study and sustainable exploitation of Marine Biological Resources" (CMBR, MIS 5002670) in the framework of the National Roadmap for Research Infrastructures is gratefully acknowledged. The involvement of Stavroula Konstantopoulou and Thalia Sokali in the extraction and isolation of bromosphaerol is gratefully acknowledged.

Conflicts of Interest: The authors declare no conflict of interest. The funders had no role in the design of the study; in the collection, analyses, or interpretation of data; in the writing of the manuscript, or in the decision to publish the results. 


\section{References}

1. Almeida, J.R.; Correia-da-Silva, M.; Sousa, E.; Antunes, J.; Pinto, M.; Vasconcelos, V.; Cunha, I. Antifouling potential of nature inspired sulfated compounds. Sci. Rep. 2017, 7, 42424. [CrossRef]

2. Bloecher, N.; Floerl, O. Efficacy testing of novel antifouling coatings for pen nets in aquaculture: How good are alternatives to traditional copper coatings? Aquaculture 2020, 519, 734936. [CrossRef]

3. Chen, L.; Duan, Y.; Cui, M.; Huang, R.; Su, R.; Qi, W.; He, Z. Biomimetic surface coatings for marine antifouling: Natural antifoulants, synthetic polymers and surface microtopography. Sci. Total Environ. 2021, 766, 1444692. [CrossRef] [PubMed]

4. Feng, K.; Ni, C.; Yua, L.; Zhou, W.; Li, X. Synthesis and antifouling evaluation of indole derivatives. Ecotoxicol. Environ. Saf. 2019, 182, 109423. [CrossRef] [PubMed]

5. Zhao, L.; Chen, R.; Lou, L.; Jing, X.; Liu, Q.; Liu, J.; Yu, J.; Liu, P.; Wang, J. Layer-by-layer-assembled antifouling films with surface microtopography inspired by Laminaria japonica. Appl. Surf. Sci. 2020, 511, 145564. [CrossRef]

6. Kolter, R.; Greenberg, E.P. The superficial life of microbes. Nature 2006, 441, 300-302. [CrossRef]

7. Leonardi, A.K.; Ober, C.K. Polymer-based marine antifouling and fouling release surfaces: Strategies for synthesis and modification. Annu. Rev. Chem. Biomol. Eng. 2019, 10, 241-264. [CrossRef]

8. Liu, S.; Guo, W. Anti-Biofouling and healable materials: Preparation, mechanisms, and biomedical applications. Adv. Funct. Mater. 2018, 28, 1800596. [CrossRef]

9. Talluri, S.N.L.; Winter, R.M.; David, R.; Salem, D.R. Conditioning film formation and its influence on the initial adhesion and biofilm formation by a cyanobacterium on photobioreactor materials. Biofouling 2020, 36, 183-199. [CrossRef]

10. Chavan, P.; Kumar, R.; Kirubagaran, R.; Venugopalan, V.P. Comparative toxicological effects of two antifouling biocides on the marine diatom Chaetoceros lorenzianus: Damage and post-exposure recovery. Ecotoxicol. Environ. Saf. 2017, 144, 97-106. [CrossRef]

11. Jagerbrand, A.K.; Brutemark, A.; Sveden, J.B.; Gren, I.M. A review on the environmental impacts of shipping on aquatic and nearshore ecosystems. Sci. Total Environ. 2019, 695, 133637. [CrossRef]

12. Majik, M.S.; Rodrigues, C.; Mascarenhas, S.; D'Souza, L. Design and synthesis of marine natural product-based 1H-indole-2,3dione scaffold as a new antifouling/antibacterial agent against fouling bacteria. Bioorganic Chem. 2014, 54, 89-95. [CrossRef]

13. Callow, M.E.; Callow, J.E. Marine biofouling: A sticky problem. Biologist 2002, 49, 10-14. [PubMed]

14. Cho, Y.; Jeon, K.H.; Lee, S.B.; Park, H.; Lee, I. Evaluation of in-service speed performance improvement by means of FDR-AF (frictional drag reducing anti-fouling) marine coating based on ISO19030 standard. Sci. Rep. 2021, 11, 1062. [CrossRef] [PubMed]

15. Hunsucker, K.Z.; Ralston, E.; Gardner, H.; Swain, G. Specialized grooming as a mechanical method to prevent marine invasive species recruitment and transport on ship hulls. In Impacts of Invasive Species on Coastal Environments; Makowski, C., Finkl, C.W., Eds.; Springer International Publishing AG: Cham, Switzerland, 2019; pp. 247-265. [CrossRef]

16. Kamensky, K.M.; Hellum, A.M.; Mukherjee, R.; Naik, A.; Moisander, P.H. Underwater shear-based grooming of marine biofouling using a non-contact Bernoulli pad device. Biofouling 2020, 36, 951-964. [CrossRef] [PubMed]

17. Manolakis, I.; Azhar, U. Recent Advances in mussel-inspired synthetic polymers as marine antifouling coatings. Coatings 2020, 10, 653. [CrossRef]

18. Schultz, M.P.; Bendick, J.A.; Holm, E.R.; Hertel, W.M. Economic impact of biofouling on a naval surface ship. Biofouling 2011, 27, 87-98. [CrossRef]

19. Almeida, E.; Diamantino, T.C.; de Sousa, O. Marine paints: The particular case of antifouling paints. Prog. Org. Coat. 2007, 59, 2-20. [CrossRef]

20. Finnegan, C.; Ryan, D.; Enright, A.M.; Garcia-Cabellos, G. A review of strategies for the detection and remediation of organotin pollution. Crit. Rev. Environ. Sci. Technol. 2018, 48, 77-118. [CrossRef]

21. Szeto, W.; Leung, M.K.H.; Leung, D.Y.C. Recent developments of titanium dioxide materials for aquatic antifouling application. J. Mar. Sci. Technol. 2021, 26, 301-321. [CrossRef]

22. Yebra, D.M.; Kiil, S.; Dam-Johansen, K. Antifouling technology-past, present and future steps towards efficient and environmentally friendly antifouling coatings. Prog. Org. Coat. 2004, 50, 75-104. [CrossRef]

23. Schøyen, M.; Green, N.W.; Hjermann, D.Ø.; Tveiten, L.; Beylich, B.; Øxnevad, S.; Beyer, J. Levels and trends of tributyltin (TBT) and imposex in dogwhelk (Nucella lapillus) along the Norwegian coastline from 1991 to 2017. Mar. Environ. Res. 2018, 144, 1-8. [CrossRef] [PubMed]

24. Thomas, K.V.; Brooks, S. The environmental fate and effects of antifouling paint biocides. Biofouling 2010, 26, 73-88. [CrossRef]

25. Chapman, J.; Hellio, C.; Sullivan, T.; Brown, R.; Russell, S.; Kiterringham, E.; Nor, L.; Regan, F. Bioinspired synthetic macroalgae: Examples from nature for antifouling applications. Int. Biodeter. Biodegr. 2014, 86, 6-13. [CrossRef]

26. Readman, J.W. Development, occurrence and regulation of antifouling paint biocides: Historical review and future trends. In Antifouling Paint Biocides. The Handbook of Environmental Chemistry; Konstantinou, I., Ed.; Springer: Heidelburg, Germany, 2006; Volume 50, pp. 1-15. [CrossRef]

27. Pistone, A.; Scolaro, C.; Visco, A. Mechanical properties of protective coatings against marine fouling: A Review. Polymers 2021, 13, 173. [CrossRef] [PubMed]

28. Tian, J.; Xu, K.; Hu, J.; Zhang, S.; Cao, G.; Shao, G. Durable self-polishing antifouling Cu-Ti coating by a micron-scale Cu/Ti laminated microstructure design. J. Mater. Sci. Technol. 2021, 79, 62-74. [CrossRef]

29. Fusetani, N. Antifouling marine natural products. Nat. Prod. Rep. 2011, 28, 400-410. [CrossRef] [PubMed] 
30. Gu, Y.; Yu, L.; Mou, J.; Wu, D.; Xu, M.; Zhou, P.; Ren, Y. Research strategies to develop environmentally friendly marine antifouling coatings. Mar. Drugs 2020, 18, 371. [CrossRef]

31. Kirschner, C.M.; Brennan, A.B. Bio-inspired antifouling strategies. Annu. Rev. Mater. Res. 2012, 42, 211-229. [CrossRef]

32. Selim, M.S.; El-Safty, S.A.; Shenashen, M.A.; Higazy, S.A.; Elmarakbi, A. Progress in biomimetic leverages for marine antifouling using nanocomposite coatings. J. Mater. Chem. B 2020, 8, 3701-3732. [CrossRef]

33. Wang, K.L.; Wu, Z.H.; Wang, Y.; Wang, C.Y.; Xu, Y. Mini-Review: Antifouling natural products from marine microorganisms and their synthetic analogs. Mar. Drugs 2017, 15, 266. [CrossRef]

34. Dahms, H.U.; Dobretsov, S. Antifouling compounds from marine macroalgae. Mar. Drugs 2017, 15, 265. [CrossRef]

35. Saha, M.; Goecke, F.; Bhadury, P. Mini review: Algal natural compounds and extracts as antifoulants. J. Appl. Phycol. 2018, 30, 1859-1874. [CrossRef] [PubMed]

36. Piazza, V.; Roussis, V.; Garaventa, F.; Greco, G.; Smyrniotopoulos, V.; Vagias, C.; Faimali, M. Terpenes from the red alga Sphaerococcus coronopifolius inhibit the settlement of barnacles. Mar. Biotechnol. 2011, 13, 764-772. [CrossRef]

37. Protopapa, M.; Kotsiri, M.; Mouratidis, S.; Roussis, V.; Ioannou, E.; Dedos, S.G. Evaluation of antifouling potential and ecotoxicity of secondary metabolites derived from red algae of the genus Laurencia. Mar. Drugs 2019, 17, 646. [CrossRef] [PubMed]

38. Cafieri, F.; Ciminiello, P.; Santacroce, C.; Fattorusso, E. Three diterpenes from the red alga Sphaerococcus coronopifolius. Phytochemistry 1983, 22, 1824-1825. [CrossRef]

39. Schade, D.; Kotthaus, J.; Klein, N.; Kotthaus, J.; Clement, B. Prodrug design for the potent cardiovascular agent Nw-hydroxy-1arginine (NOHA): Synthetic approaches and physicochemical characterization. Org. Biomol. Chem. 2011, 9, 5249-5259. [CrossRef] [PubMed]

40. Walters, I.; Birch, L.; Hill-Cousins, J.; Collingwood, S.P.; Stevenson, C.S. Indolinones Compounds and Their Use in The Treatment of Fibrotic Diseases. U.S. Patent WO 2017/109513 A1, 29 June 2017.

41. Rittschof, D.; Clare, A.S.; Gerhart, D.J.; Sister Avelin, M.; Bonaventura, J. Barnacle in vitro assays for biologically active substance: Toxicity and settlement inhibition assay using mass cultured Balanus amphitrite Darwin. Biofouling 1992, 6, 115-122. [CrossRef]

42. Finney, D.J. Bioassay and the practice of statistical inference. Int. Stat. Rev. Rev. Int. Stat. 1979, 47, 1-12. [CrossRef] 